This is an author produced version of a paper published in FIELD CROPS RESEARCH. This paper has been peer-reviewed and is proofcorrected, but does not include the journal pagination.

Citation for the published paper:

Jensen, Erik Steen, Peoples, Mark B., Hauggaard-Nielsen, Henrik. (2010)

Faba bean in cropping systems. Field crops research. Volume: 115 Number: 3, pp 203-216. http://dx.doi.org/10.1016/j.fcr.2009.10.008

Access to the published version may require journal subscription. Published with permission from: Elsevier

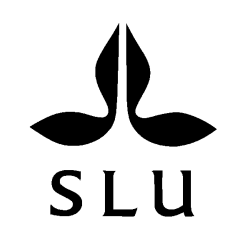

Epsilon Open Archive http://epsilon.slu.se 


\section{$1 \quad$ Faba bean in cropping systems}

2

$3 \quad$ Erik S. Jensen ${ }^{1}$, Mark B. Peoples ${ }^{2}$ and Henrik Hauggaard-Nielsen ${ }^{3}$

4

$5 \quad{ }^{1}$ Swedish University of Agricultural Sciences, PO Box 104, 23053 Alnarp, Sweden, ${ }^{2}$ CSIRO

Plant Industry, G.P.O. Box 1600 Canberra, ACT 2601, Australia. ${ }^{3}$ Risø National Laboratory for

Sustainable Energy, Technical University of Denmark, 4000 Roskilde, Denmark

8

9

*Corresponding author: Erik Steen Jensen, Department of Agriculture - Farming Systems, Technology and Product Quality, Swedish University of Agricultural Sciences, PO Box 104, SE 23053 Alnarp, Sweden.

Telephone: $\quad$ +46 40415035

Fax: $\quad+4540462166$

E-mail: $\quad$ erik.steen.jensen@ltj.slu.se

15

Figures: 7

18

Tables : 4 


\section{Abstract}

The grain legume (pulse) faba bean (Vicia faba L.) is grown world-wide as protein source for food and feed, but at the same time faba bean offers ecosystem services such as renewable inputs of nitrogen $(\mathrm{N})$ into crops and soil via biological $\mathrm{N}_{2}$ fixation, and a diversification of cropping systems. Even though the global average grain yield has almost doubled during the past 50 years the total area sown to faba beans has declined by 56\% over the same period. The season-toseason fluctuations in grain yield of faba bean and the progressive replacement of traditional farming systems, which utilized legumes to provide $\mathrm{N}$ to maintain soil $\mathrm{N}$ fertility, with industrialized, largely cereal-based systems that are heavily reliant upon fossil fuels (= $\mathrm{N}$ fertilizers, heavy mechanization) are some of the explanations for this decline in importance. Past studies of faba bean in cropping systems have tended to focus on the effect of faba bean as a pre-crop in mainly cereal intensive rotations, whereas similar information on the effect of preceding crops on faba bean is lacking. Faba bean has the highest average reliance on $\mathrm{N}_{2}$ fixation for growth of the major cool season grain legumes. As a consequence the $\mathrm{N}$ benefit for following crops is often high, and several studies have demonstrated substantial savings (up to 100-200 kg N ha ${ }^{-1}$ ) in the amount of $\mathrm{N}$ fertilizer required to maximize the yield of crops grown after faba bean. There is, however, a requirement to evaluate the potential risks of losses of $\mathrm{N}$ from the plant-soil system associated with faba bean cropping via nitrate leaching or emissions of $\mathrm{N}_{2} \mathrm{O}$ to the atmosphere as a consequence of the rapid mineralization of $\mathrm{N}$ from its $\mathrm{N}$-rich residues. It is important to develop improved preventive measures, such as catch crops, intercropping, or no-till technologies, in order to provide farmers with strategies to minimize any possible undesirable effects on the environment that might result from their inclusion of faba bean in cropping system. This needs to be combined with research that can lead to a reduction in the current extent of yield variability, so that faba bean crop may prove to be a key component of future arable cropping systems where declining supplies and high prices of fossil energy are likely to constrain the affordability and use of fertilizers. This will help address the increasing demand by consumers and governments for agriculture to reduce its impact on the environment and climate through new, more sustainable approaches to food production. The aims of this 
paper are to review the role of faba bean in global plant production systems, the requirements for optimal faba bean production and to highlight the beneficial effects of faba bean in cropping systems.

Keywords: Break-crop effect; Crop rotation; Nitrogen dynamics; $\mathrm{N}_{2}$ fixation; Vicia faba L.

\section{Introduction}

Faba bean (Vicia faba L., broad bean, horse bean) is grown world-wide in cropping systems as a grain (pulse) and green-manure legume. The faba bean contributes to the sustainability of cropping systems via: 1 ) its ability to contribute nitrogen $(\mathrm{N})$ to the system via biological $\mathrm{N}_{2}$ fixation, 2) diversification of systems leading to decreased disease, pest and weed build-up and potentially increased biodiversity, 3) reduced fossil energy consumption in plant production, and 4) providing food and feed rich in protein. Yet despite this, faba bean was only grown on c. 2.6 mill ha in recent years (FAOSTAT, 2008), which is comparable to just $39 \%$ of the global dry pea (Pisum sativum L.) area and only 3\% of the soybean (Glycine max L.) area. The area sown to faba bean has been declining in the main countries of production such as China, and reflects a general trend since the 1960's for an increasing reliance by farmers upon $\mathrm{N}$ fertilizers rather than legume systems as a source of $\mathrm{N}$ input (Smil, 2001; Crews and Peoples, 2004). The productivity of most cereal-based cropping systems (wheat [Triticum aestivum L.]: 216 mill. ha, rice [Oryza sativa L.]: 154 mill. ha and maize [Zea mays L.]: 144 mill ha; FAOSTAT, 2008) are now strongly dependent on fossil energy for $\mathrm{N}$ fertilizer manufacture, transport and spreading (Smil, 2001). The limited resources of fossil energy, the emissions of $\mathrm{CO}_{2}$ as a result of the production, distribution and application of fertilizer $\mathrm{N}$, and the health and environmental implications of the losses of large amounts of $\mathrm{N}$ from fertilized soils as a consequence of inefficiencies in plant use of fertilizer N (Peoples et al., 2004; Crews and Peoples, 2005), suggests that it is timely to reassess the potential role of legumes, such as faba bean, as a source of $\mathrm{N}$ for future cropping systems (Jensen and Hauggaard-Nielsen, 2003; Crews and Peoples, 2004) .

A cropping system is characterized by three main factors: 1) the nature of the crops and pastures in the system and how they respond to and affect the biological, chemical and physical environment, 2) the succession of crops and pastures in the system (from monoculture to species 
102

rich dynamic or fixed rotations) and 3) the series of management techniques applied, including varieties of crop and pasture species in the system. To develop successful cropping systems it is necessary to understand how a crop such as faba bean responds to biological, chemical, physical, and climatic variables, and how this response can be influenced by management. It is also important to determine how faba bean cultivation affects the productivity of subsequent crops (Sebillotte, 1995; Crozat and Fustec, 2006; Peoples et al., 2009a). A farmer’s decision about which cropping system to adopt will be based on: 1) externalities to the farm such as the climate change, markets, regulations and the availability of new technologies, and 2) the farmer's own goals about production requirements, economics, and environmental stewardship, and attitude to factors such as risk (Tanaka et al., 2002). To develop sustainable cropping systems is a complex task, which involves many parameters, and it requires the necessary knowledge to be able to respond to sudden changes in these parameters at different scales, e.g. in the market or in parts of a field. The challenge is to exploit synergism in time and space through crop sequencing to enhance crop yields with improved resource use efficiency and a reduced risk of negative impacts on the environment via integration of ecological and agricultural sciences. Thus considering the performance and effects of faba bean in a cropping system requires knowledge on how faba bean reacts to the environment created by the preceding crops and management before and during cropping in addition to how the faba bean modifies the environment for the subsequent crops in the system. The encouraging research findings on faba bean's ability to fix $\mathrm{N}_{2}$ and to benefit following crops, and the emerging problems with pea cultivation in some regions with a high proportion of peas in the rotation, may also be factors which can stimulate a renewed interest for the use of faba bean in future sustainable cropping systems.

The aims of this paper are to: 1 ) review the role of faba bean in global plant production systems, 2) review the requirements for optimal faba bean production in cropping systems, 3) highlight the beneficial effects of faba bean in cropping systems, and 4) point to possibilities for expanding the use of faba bean for food, feed and fuel production as well as its potential for providing ecosystems services.

\section{Faba bean in cropping systems}

\subsection{Uses, world acreage, proportion in arable systems and yield}


Faba bean is native in the Near East and Mediterranean basin and has been cultivated for c. 810,000 years (Zohary and Hopf, 2000), and it is an important winter crop in warm temperate and subtropical areas. It is a significant source of protein rich food in developing countries and is used both as a human food and a feed for pigs, horses, poultry and pigeons in industrialized countries (Duke, 1981). Faba bean is most commonly included in the diets of inhabitants of the Middle East, the Mediterranean region, China and Ethiopia, and it can be used as a vegetable, green or dried, fresh or canned (Bond et al., 1985). The nutritional value of faba bean is high, and in some areas is considered to be superior to peas or other grain legumes (Crépon et al., this issue). Faba bean is also grown for green manure and can significantly enhance yields of cereals or other crops (e.g. Wani et al., 1994). Faba bean straw is also considered as a cash crop in Egypt and Sudan (Bond et al., 1985).

Faba bean production is more evenly distributed around the world than most other grain legumes. The date of introduction of faba bean (var. minor) to China is believed to be around 100 BC (Bond et al., 1985). The cultivated faba bean world area was estimated to be 2.6 million ha in 2006, with $40 \%$ of the total global area of production being located in China followed by Ethiopia and the European Union with 16 and 10\%, respectively (FAOSTAT, 2008). The UK, France, Spain and Italy were the main producers in Europe with >100,000, 78,000, 56,000 and 45,000 ha, respectively. There has been a 56\% decline in the area sown to faba bean since 1962 , but the total production has only decreased by about 20\%, since the average yield almost doubled (from c. 1 to 1.8 tonnes ha $^{-1}$ ) during the same period. Migration of people from rural areas reduced the need for faba bean as a basic food, greater dependence on imported feedstuffs, unstable grain yields due to production on marginal land, the prevalence of low cost $\mathrm{N}$-fertilizer replacing the need for legume systems to supply $\mathrm{N}$, the susceptibility to a range foliar fungal diseases (e.g. Chocolate spot, Botrytis fabae; Ascochhyta blight, Ascochyta fabae; Cercospora leaf spot, Cercospora zonata; Downy mildew, Peronospora viciae) that may require fungicide treatment for control which adds to the production costs (Stoddard et al., this issue), and the occurrence of parasitic weeds in some areas (e.g. Orobanche crenata) are among the many factors that have contributed to a decline in popularity with farmers and the reduction in the cultivated area (Cubero, 1981; Smil, 2001; Perez-de- Luque et al., this issue;). In fact all legumes, except soybean, have declined in area since the early 1960’s. However, the inclusion of 
more legumes in a cropping sequence could greatly contribute to reduced fossil energy use and greenhouse gas emissions (Nemecek et al., 2008, Peoples et al., 2009b).

In some countries, such as Egypt, the proportion of total arable land sown to faba bean has rarely been more than 6\% since 1965 (Fig. 1a). In China the proportion of faba bean has been in a steady decline from 3.5\% to less than 1\% of the arable land by 2005 (Fig. 1a). In the industrialized countries, with the exception of Italy, the proportion of faba bean in arable cropping systems never exceeded 1\% within the last 50 years and in some countries (e.g. UK) the proportion of faba bean seems extremely variable (Fig. 1b). In Italy the proportion of faba bean has declined from c. 4\% in 1960 to about 0.5\% in 2006 (FAOSTAT, 2008). In France the recent slight increase in faba bean area may be due to substitution of pea with faba bean, due to a too intensive cultivation of pea causing pea disease problems (e.g. Aphanomyces).

The global average faba bean yield in 2006 was 1.8 tonnes/ha (FAOSTAT, 2008), but yields are highly variable within specific countries (Fig. 2). The FAOSTAT (2008) data show that the yield increase during the past 50 years has been much greater in France $(64 \mathrm{~kg} / \mathrm{year})$ and Egypt (35 kg/year) than in China (22 kg/year) (Fig. 2a). In UK, Australia or Canada average yield are more stable during the past three decades, but highly variable (Fig. 2b). There is a strong requirement for yield stabilization world wide and greater yield improvement in some countries, as there is limited scope for bringing additional land into cultivation. About $46 \%$ of total world production comes from the approximately 1.05 million ha in China followed by the European Union, Ethiopia and Egypt with 15, 13 and 7\% respectively of the world production in 2006 (FAOSTAT, 2008). The North African contribution highlights the role of faba bean as a basis protein food in this part of the world. We conclude that if major limitations to faba bean yields can be overcomed, there is a huge potential world-wide for increasing the frequency of faba bean and other legumes in cropping systems.

\subsection{Faba bean position and frequency cropping systems}

For best production faba bean crops should be grown on well-structured loam or clay soils with a $\mathrm{pH}$ of 6.5 to 9.0. They perform poorly on light sandy soils, and nodulation failures can occur on acidic soils, especially if they are hard setting or prone to waterlogging. Plants are reasonably 
tolerant to waterlogging, but are more prone to infection from foliar diseases such as Chocolate spot under waterlogged conditions.

Faba bean are grown during winter in subtropical and warmer temperate climates on water remaining after crops such as maize and sorghum (Sorghum bicolour L.) (Pala et al., 1994). Precipitation is often low and is a strongly limiting factor on the grain yield. The West Asia and North African region has a Mediterranean-type climate with hot dry summers and wet mild winter-dominant rainfall patterns (Pala et al., 1994). Faba bean are grown under rain-fed conditions during the winter and typically rotated with cereals, cotton (Gosypium hirsutum L.), sugar beet (Beta vulgaris L.) in the coastal regions. In China faba bean is typically autumn-sown after rice (Oryza sativa L.), or intercropped with cotton or maize in southern and Western provinces (Zhang et al., 2004), whereas it is grown in rotation with winter wheat and also intercropped with cereals in the Northern provinces (Pala et al., 1994). In Northern parts of Europe faba bean is primarily spring-sown in cropping systems with cereals, oilseed rape (Brassica napus L.) and sugar beets. Preceding crops to faba bean in rain-fed systems in Australia would almost certainly be either wheat or barley (Hordeum vulgare L.). The faba bean crop would generally be followed by either wheat or oil seed rape. Faba bean is also used in rotation with irrigated cotton (when the country is not in drought) to some degree and in that case cotton would usually be the main crop before and after. However, if irrigation water is not available faba bean would be followed by wheat.

Despite many studies with faba bean in cropping systems (e.g. McEwen et al., 1989; Pare et al., 1993; Rochester et al., 2001; Lopez-Bellido et al., 2007; Walley et al., 2007), there seems to be a serious knowledge gap concerning which preceding crop species and what management regimes are able to create the most suitable environment for a succeeding faba bean crop. The focus of most research has been on the influence of faba bean on following crops (see below). This highlights the lower priority given to faba bean (and other legumes) regarding the optimization of the biological, physical, chemical environment for optimal and stable faba bean growth and yield formation, which contributes to the yield instability observed in faba bean and other legume species.

Faba bean is typically followed by one or more cereals to exploit the "break-crop" and $\mathrm{N}$ effect of faba bean in a cropping system. The succeeding crops should ideally have a long 
growth period to make most efficient use of $\mathrm{N}$ mineralized late in the growing season. However, the duration of the faba bean pre-crop effect has not been studied in great detail, since it can be confounded by the subsequent crops. Nonetheless, Pare et al. (1993) was able to demonstrate that maize whole-plant dry matter yields were enhanced in the third corn crop following faba bean as compared to continuous maize. Wright (1990) also observed significant yield increases $(12 \%)$ in the second cereal following faba bean compared to $\mathrm{N}$ fertilized continuous cereals.

Ultimately the main constraint to increasing the frequency of faba bean in a rotation is determined by the effects on soil-borne disease and pests, and it is usually recommended that the maximum frequency a susceptible crop should be grown is only once in 4-5 years (Slinkard et al., 1994). This is largely related to different root and stem rot diseases (Fusarium, Pythium, Phoma, Sclerotinia), which can utilize a number of cool-season legume crops species in addition

\subsection{Winter or spring - sole or intercrop of faba bean}

The choice of winter or spring faba bean depends very much on the climate, the soil type and cropping system. In climates with warm winter temperatures and on heavy clay soil that are difficult to till in the spring there is a preference for winter beans, since they are able to use autumn and winter moisture and mature early. Spring beans are vulnerable to summer drought and depends on early summer precipitation to obtain high yields. Consequently, early sowing is extremely important. New early spring bean cultivars are available and in some cases they may mature earlier than winter sown beans (PGRO, 2008).

Most faba bean crops in the industrialized countries are sole cropped, but in other parts of the world (e.g. China) intercropping of faba bean with maize or other cereals is a common practise (Zhang et al., 2004; Li et al., 2009). Intercropping was also previously common in Europe and other part of the world, but "fossilization" of agriculture with N-fertilizers, mechanization and pesticides have gradually eliminated intercrops of grain legumes and nonlegumes in the industrialized countries. However, intercropping may be revitalized in the Western world, especially in organic agriculture (Jensen, 2006). Intercropping can improve the use of resources (land, nutrients - especially soil nitrogen, light, water) by $10-50 \%$ above sole crops grown on the same piece of land expressed in the Land Equivalent Ratio (LER) (Willey, 
1979; Martin and Snaydon, 1982; Bulson et al., 1997; Hauggaard-Nielsen et al., 2008). LER is the sum of the relative yields of the intercrop components relative to their respective sole crop yield. The yield stability may also be improved (Jensen, 1986a) and intercropping can enhance the grain quality (Gooding et al., 2007)

The benefits of intercropping are of special interest in cropping systems, where the intends using the grain on farm. This is because there are not yet sufficient markets for mixed grain (e.g. faba bean and wheat) even though low cost separation machinery for the grain is available. The advantages of intercropping are derived from the "competitive interference principle” (Vandermeer, 1989), in which the interspecific competition between intercrop component species will be less than the intraspecific competition in sole crops. This is based on different growth patterns, more efficient interception of light and use of water and nutrients over the growing season, due to different patterns of water and nutrient uptake by the intercropped species (Willey, 1979). Nitrogen sources from $\mathrm{N}_{2}$ fixation and soil will generally be utilized more efficiently, since the greater competitive ability of the cereal component for soil mineral $\mathrm{N}$ (or fertilizer $\mathrm{N}$ ) results in a reduced uptake of soil $\mathrm{N}$ and higher dependence upon $\mathrm{N}_{2}$ fixation by intercropped faba bean compared to a faba bean crop (Fig. 3; Knudsen et al., 2004; HauggaardNielsen et al., 2008; Li et al., 2009).

Hauggaard-Nielsen et al. (2008) reported that when comparing intercropping of faba bean or pea with barley cultivars on two soil types, faba bean was a better choice than pea, due to better spatial or temporal complementarity with the barley companion crop (Fig. 3). Typically the grain yield of a faba bean and cereal intercrop without $\mathrm{N}$-fertilizer was similar to the grain yield of the sole crop cereal fertilized with an optimal amount of $\mathrm{N}$ fertilizer, but total protein yield was significantly greater, due to the faba bean content in the mixed grain (Jensen, 1986a; Knudsen et al., 2004, Hauggaard-Nielsen et al., 2008). To maximize the use of resources, especially of $\mathrm{N}$, it is important that the intercrop components differ in their competitive ability, and that it is the cereal, which is the more competitive crop for soil N. This is exemplified in Fig. 4 showing the effects of intercropping faba bean with pea, narrow leaf lupin (Lupinus angustifolius L.) and barley in dual, triplicate or quadruple intercrops without $\mathrm{N}$ fertilization (Hauggaard-Nielsen, unpublished). Thus, intercropping of grain legumes species does not seem 
advantageous, as can be observed from the LER values in Fig. 4 (LER $>1=$ advantage, LER < 1 = disadvantage). From the proportion of crops in the grain yield, it can also be observed that pea was the most competitive component to faba bean. Intercrops in which the grain legume is dominant may be less advantageous. This was observed in intercrops of faba bean and maize in Denmark, where the slow establishment of maize resulted in faba bean being the dominant crop and there was virtually no advantage from intercropping (Jensen, 1986b). However, under different climatic conditions faba bean-maize seems more advantageous than faba bean wheat intercrops (Fan et al., 2006). Studies on the effect of intercrop design of spring faba bean and more intimate the components were growing the more competitive was the wheat, but the intercropping advantage and total yield was not significantly different (Martin and Snaydon, 1982; Jensen, 1986a). The proportion of faba bean in the mixed harvested grain was increased from 37 to 51\% (without fertilizer $\mathrm{N}$ ) and 22 to $38 \%$ (with $50 \mathrm{~kg} \mathrm{~N}^{-1}$ ), when the row design was changes from mixed in the same row to alternating double rows, respectively.

Intercropping of faba bean with cereals may be an efficient management tool to control weeds; particularly if no appropriate herbicides are available, or where herbicides cannot be used such as in organic farming systems (Hauggaard-Nielsen et al., 2008). Growing the cereal with faba bean will ensure earlier canopy closure and soil cover, which can otherwise be difficult to obtain with a spring-sown faba bean crop. The intercropped cereal will also generally compete better than faba bean with weeds for water and nutrients, and weed development in a faba beancereal intercrops tend to be markedly lower than with a sole faba bean crop (Bulson et al., 1997). Recently it has also been shown that legume parasitic weed broomrape can be controlled by intercropping faba bean with cereals (Fernández-Aparicio et al., 2007). The number of broomrape attachments on faba bean and emerged broomrape plants were significantly reduced by intercropping with oat (Avena sativa L.), barley and other species. Similarly, there is now evidence indicating a reduction in incidence and severity of disease in faba bean and its intercrop component when the crops are grown together rather than separately (Hauggaard-Nielsen et al., 2008; Kinane and Lyngkjær, 2002). However, until the appropriate investigations on the buildup of pathogenic inoculum within intercropping systems have been undertaken, it is still probably prudent to ensure that neither of the intercropped components occur more frequently in 
a rotation than is desirable for sole crops, since it has not been determined to which degree a faba bean-cereal intercrop is able to break disease cycles.

\subsection{Faba bean for green manure and biomass for bioenergy}

Using the faba bean biomass of 5-13 t DM ha- ${ }^{-1}$ as a green manure results in large inputs of organic $\mathrm{N}$ and carbon (C) to the soil, which in the long-term significantly stimulates microbial biomass $\mathrm{C}$ and $\mathrm{N}$, enhance soil fertility, influence soil structure and water-holding capacity, improve the supply of mineral $\mathrm{N}$, and improve the yield potential of crops compared to continuous cereal systems relying on N-fertilizers (e.g. Wani et al., 1991). Enhanced fertility is of significant importance for the future capacity of the soil to sustain food production. But it is also necessary to consider the possible role that faba bean green manuring may play in increasing the risk of nutrient loss; especially losses of $\mathrm{N}$ via nitrate leaching to the groundwater, or through denitrification and the production of the potent greenhouse gas $\mathrm{N}_{2} \mathrm{O}$.

Some of the old, indeterminate cultivars of faba bean with an extremely high biomass production may be suited for use as "biomass crops", possibly intercropped with high yielding, perennial monocots, to be used in biorefineries for biofuels, biogas, green chemicals, power and recycling of nutrients to agricultural land. The attraction of using a productive legume such as faba bean is its ability to supply its own $\mathrm{N}$ via symbiotic $\mathrm{N}_{2}$ fixation. Supplying $\mathrm{N}$ inputs as fertilizer to grow non-legume biomass crops for biofuel purposes essentially negates the whole of life-cycle energy cost and reduces the $\mathrm{C}$ neutrality because of the fossil fuels involved in fertilizer production and the emission of $\mathrm{N}_{2} \mathrm{O}$ from $\mathrm{N}$ fertilizer (Crutzen et al., 2007; Peoples et al., 2009b). There could be ways that the high protein content of the legume can be valued to cover the additional costs (e.g. biorefinery use of the protein fraction so it can be used for animal feed). If the faba bean biomass is used for starch or lignocellulose, soil fertility issues must also be considered as less organic $\mathrm{N}$ will be available to maintain long-term soil fertility (Peoples et al., 2009a). To avoid nutrient depletion and soil degradation it would also be necessary to be mindful of the need to replace limited nutrients such as phosphorus (P) that are taken up by faba bean in large amounts (see section 3.2), if these are not recycled to the agro-ecosystems. the soil 
Faba bean is a long-day plant and requires a cool season for best development and can be seeded early. The crop is grown as a winter annual in warm temperate and subtropical areas; hardier cultivars in the Mediterranean region tolerate winter temperatures of $-10^{\circ} \mathrm{C}$ without serious injury, whereas the hardiest European cultivars can tolerate up to $-15^{\circ} \mathrm{C}$. Growing seasons should have little or no excessive heat, optimum temperatures for production range from 18 to $27^{\circ} \mathrm{C}\left(65-85^{\circ} \mathrm{F}\right) "$ (Duke, 1981; Link et al., this issue). Faba beans are late maturing so they benefit from a longer growing season, which will influence the timing and autumn development including $\mathrm{N}$ uptake of the subsequent crop in the cropping system.

\subsection{Soil and non- $\mathrm{N}$ nutrient requirements}

Faba beans grow best on heavier-textured soils, but tolerate nearly any soil type (Duke, 1981; summer, which can have detrimental effects on yields. Unfortunately faba bean is often grown on marginal soils, and is commonly considered to be of lower priority in the cropping system management by farmers, which can lead to late sowing, water stress, poor weed control, late harvesting and grain losses.

Rochester et al. (2001) demonstrated that the vigorous tap-roots of faba bean and other legumes can reduce the soil strength for a succeeding cotton crop compared to continuous cotton and cereals as pre-crops. Measuring the field soil strength is an efficient means of diagnosing mechanical resistance to root growth. It was deduced that faba bean may improve the structure of poorly structured soil by stabilizing soil aggregates (Rochester et al., 2001).

The seasonal nutrient requirement of a spring-sown faba bean crop yielding $5 \mathrm{t}$ grain $\mathrm{ha}^{-1}$ has been determined by Jensen et al. (unpublished, 1985b) (Table 1). Whereas the $\mathrm{N}$ concentration in the biomass decreased sharply (5\% to $2.8 \%$ ) from prior to flowering to early pod-filling the $\mathrm{P}$ concentration remained almost constant around $0.35 \%$ implying that the $\mathrm{P}$ uptake rate follows (or regulates) dry matter production (Jensen et al., 1985b). The potassium (K) concentration decreased steadily from onset of reproductive growth until maturity (3.0\% to $1.5 \%)$. The decline in $\mathrm{K}$ concentration may be associated with some $\mathrm{K}$ being leached from the above-ground herbage during maturation. 
Faba bean seeds have greater N, P and Ca concentrations than pea seeds, whereas faba bean empty pods were lower in $\mathrm{N}, \mathrm{P}, \mathrm{Ca}$ and magnesium (Mg) than pea empty pods (Table 1). Faba bean pods are rich in $\mathrm{K}$ and sodium $(\mathrm{Na})$. When comparing stubble of faba bean and pea remaining after grain harvest, faba bean had lower $\mathrm{N}, \mathrm{K}$, Ca and $\mathrm{Mg}$ concentrations than of pea, but greater Na concentrations (Table 1). Finally, the concentration of most nutrients in roots (from simple excavation from the plough layer) indicated that faba bean had lower concentrations than pea except for $\mathrm{K}$ and $\mathrm{Na}$.

The faba bean crop had accumulated $12.4 \mathrm{t}$ dry matter ha ${ }^{-1}$ by maturity and had 352 assimilated a total of $324 \mathrm{~kg} \mathrm{~N}, 36 \mathrm{~kg}$ P, $197 \mathrm{~kg} \mathrm{K,} 12 \mathrm{~kg} \mathrm{Na}, 106 \mathrm{~kg}$ Ca and $18 \mathrm{~kg}$ Mg per ha (Table 1). This accumulation was 19, 12, 47, 310, -14 and $21 \%$, respectively, greater than in pea, which suggested that faba bean generally has greater nutrient requirements than pea. The 355 proportion of $\mathrm{N}$ and $\mathrm{P}$ removed with the grain was greater in faba bean $(71 \%$ and $82 \%$, respectively) than in pea (67\% and $72 \%$ ), whereas the proportion of $\mathrm{K}, \mathrm{Na}$ and $\mathrm{Mg}$ removed by faba bean was greater than in pea (Table 1). Similar proportions of Ca were removed. Similar amounts of $\mathrm{N}$ were found in faba bean and pea stubble (c. $90 \mathrm{~kg} \mathrm{~N} \mathrm{ha}^{-1}$ ), less $\mathrm{P}$ and Ca in faba bean, more $\mathrm{Na}$ and $\mathrm{Mg}$ in faba bean and much more $\mathrm{K}$ in faba bean residues than in pea residues (134 vs. $78 \mathrm{~kg} \mathrm{~K} \mathrm{ha}^{-1}$ ).

Studies (pot experiments) of faba bean response to $\mathrm{P}$ fertilization have shown that during early growth stages the $\mathrm{P}$ response in faba bean and other large seed legumes is less than in wheat and oil seed rape (Bolland et al., 1999). It is suggested that the lack of response in faba bean may be due to the large P reserves in the seed. Field experiments showed that at maturity faba bean had a greater response to P than white lupin (Lupinus albus L.) and chickpea (Cicer 366 arietinum L.) (Bolland et al., 1999),

High boron (B) and Na levels often occur together and are frequently associated with soil salinity. High levels of $\mathrm{B}$ and $\mathrm{Na}$ are toxic to plants. Boron toxicity causes reduced plant growth, marginal necrosis and in extreme cases, plant death. As a general rule, pulses are more sensitive to boron toxicity than cereals, but critical levels at which boron begins to reduce the growth of grain legumes have not yet been determined. Some cultivars of field pea, faba bean and vetch appear to tolerate boron toxicity, well whereas lentil and chickpea are considerably more sensitive. Faba bean is more sensitive to high $\mathrm{Na}$ levels than pea and lentil (Poulain and $\mathrm{Al}$ 
Mohammad, 1995; Choi et al., 2006). Boron deficiency is not common, but as with other micronutrients limited knowledge is available, since deficiency symptoms are seldom observed.

\subsection{Water supply and use efficiency}

Leaf development in spring-sown faba bean in the northern hemisphere tends to be slower than a cereal such as oat, and peaks at a leaf are index (LAI) around 5 in mid July (Schmidtke, 2006) compared to early June in oat with subsequent consequence of temperature effects on transpiration rate and total dry matter production being lower in faba bean than in oat. The faba bean roots reached a depth of $0.6 \mathrm{~m}$ early July, but oat roots were observed down to $1.5 \mathrm{~m}$ in a loess soil (Schmidtke, 2006). Faba bean and oats extracted similar amounts of water from the top soil, but oats extracted more water below $0.8 \mathrm{~m}$, due to its deeper root system. Schmidtke (2006) concluded that the water spared by faba bean in the deeper soil layer, could benefit the subsequent crops in water-limited environments, where there are constraints to the replenishment of the soil water reserves. This is consistent with the findings of Lopez-Bellido et al. (2007), who observed that a preceding faba bean crop resulted in the highest yield and water use efficiency in by a following wheat compared to other pre-cropping options.

Sprent et al. (1977) suggested that soil moisture was a more important factor in determining the spring-sown faba bean yield than either solar radiation or plant competition. This is of special importance in the period following pod setting, when the supply of water is essential for pod retention, $\mathrm{N}_{2}$ fixation, photosynthesis and translocation of photosynthates to pods and root nodules (Sprent et al., 1977; Sprent and Bradford, 1977; Siddique et al., 2001). Comparing several cool-season grain legume species in a Mediterranean-type environment on fine textures soils Siddique et al. (2001) found that faba bean had the greatest water use efficiency (WUE) for dry matter production (30 $\left.\mathrm{kg} \mathrm{ha}^{-1} \mathrm{~mm}^{-1}\right)$; although WUE for grain $\left(13 \mathrm{~kg} \mathrm{ha}^{-1} \mathrm{~mm}^{-1}\right)$, tended to be lower than for pea $\left(16 \mathrm{~kg} \mathrm{ha}^{-1} \mathrm{~mm}^{-1}\right)$. In another study, Schmidtke (2006) found that the WUE for shoot biomass of faba bean (26 kg ha ${ }^{-1} \mathrm{~mm}^{-1}$ ) to be slightly lower than of oats (26 kg ha ${ }^{-1}$ $\mathrm{mm}^{-1}$ ). Siddique et al. (2001) concluded that the major trait for adapting faba bean to produce large yields in a low rainfall environment is early flowering, pod and seed set, enabling access to more soil water during post flowering before the onset of terminal drought. 
Due to the shallower root system of spring compared to autumn-sown faba beans the spring-sown types are more sensitive to water stress and the crop responds strongly to water deficits during flowering and early pod filling via many physiological effects (see Green et al., 1986; Sprent and Bradford, 1977). Saxena et al. (1986) showed that alleviating moisture stress had a greater effect than alleviating nutrient supply constraints. Even though rain-fed faba bean can produce impressive biomass yields in dryland Mediterranean conditions (Loss and Siddique, 1997), irrigation (if available) should be prioritized during these growth stages, since root growth ceases at the beginning of pod fill (Green et al., 1986; Sprent et al., 1977). Green et al. (1986) observed that the effect of irrigation during and after flowering was not due to an effect on the partitioning of dry matter for the grain, but rather a general increased biomass production. In faba bean breeding drought tolerance can be screened by a combination of leaf temperature measurement and other tests of stomatal characteristic followed by carbon isotope discrimination

\subsection{Micro-symbionts}

Faba beans form a symbiotic relationship with the soil bacteria Rhizobium leguminosarum bv. viciae and with the fungi arbuscular mycorrhizae. Most cultivated soils contain large populations of indigenous rhizobia and mycorrhizae for faba bean and inoculation is usually not required; particularly if the land had previously been sown to faba bean (Murinda and Saxena, 1985; Jensen, 1987; Patriquin, 1986). When faba beans are inoculated on soils containing indigenous populations the inoculant strain may be responsible for a large proportion of the nodules (Carter et al., 1994). However, Amarger (1986) found that about one third of the R. leguminosarum strains recovered from French soils where fix ${ }^{\text {minus }}$, meaning that the nodules were not effective in $\mathrm{N}_{2}$ fixation. Furthermore, it has been shown, that there may be interaction between strains of rhizobia and faba bean genotypes, whereby one strain may be very efficient with one faba bean genotype, but perhaps inefficient on another faba bean genotype (Mytton et al., 1977). In most cases the plant will be infected by many different strains, some of which are likely to be efficient. Consequently, inoculation will generally be of most interest where either efficient rhizobia are absent from the soil because faba bean, or other legumes such as pea or lentil which are nodulated by compatible rhizobial strains, have never been sown, or if superior inoculant 
strains are developed that are competitive with the indigenous strains (Amager, 1986; Brockwell et al., 1995).

In acid soils with $\mathrm{pH}$ lower than 5 , the survival and persistence of faba bean rhizobia are most likely to be poor and inoculation may be required after liming (Unkovich et al., 1997). Several micronutrients are also important in the infection, development and function of the root nodule, but limited information is available on deficiencies in micronutrient supply (Stanforth et al., 1994). On low $\mathrm{P}$ soils there may be a positive interaction between mycorrhizal activity and $\mathrm{N}_{2}$ fixation by legumes. Since $\mathrm{P}$ is a key nutrient in legume nutrition, populations of mycorrhizae which can infect faba bean roots may play an important role in supporting plant growth by assisting the supply of additional P; especially in soils with low plant-available P. Cropping systems which include crops of the family Brassicaceae, which are not infected by mycorrhizae, may have critically low populations, similar to where soil is treated with fungicides, or kept bare (George et al., 1994). This potentially could limit access to soil P by faba bean if it is grown immediately after a brassica crop.

\section{Role of faba bean in nitrogen cycling}

As with other legumes, faba bean can deliver an important ecosystem service to cropping systems via its ability to symbiotically fix atmospheric $\mathrm{N}_{2}$. However, initially faba bean will depend on seed $\mathrm{N}$ sources and mineral $\mathrm{N}$ during seedling emergence until nodules are established. Provided the soil contains sufficient populations of effective rhizobia faba bean can accumulate $\mathrm{N}$ both from soil and the atmosphere. The relative contribution from each source to satisfying faba bean's $\mathrm{N}$ requirements for growth will be heavily influenced by the concentrations of available soil mineral $\mathrm{N}$ in the rooting zone (Peoples et al., 2009a). Faba bean's subsequent contribution to the N-economy of the remainder of the cropping system can be derived from either: 1) unused ("spared”) soil mineral $\mathrm{N}$ and rhizodeposits of $\mathrm{N}$ remaining after crop growth, 2) $\mathrm{N}$ mineralized from above-ground organic residues and the nodulated roots following grain harvest, or 3) via $\mathrm{N}$ in animal manures and urine when the faba bean grain is used as animal feed or its residues are grazed. It is essential to be able to determine the potential net $\mathrm{N}$ benefit of faba bean in order to appropriately adjust the supply of fertilizer $\mathrm{N}$ for later crops in the rotation. 
Comparisons of the $\mathrm{N}$ dynamics of an indeterminate spring-established faba bean cultivar with pea indicated slower rates of $\mathrm{N}$ accumulation by faba bean during the first months after seedling emergence, but after two months of growth the rate of $\mathrm{N}$ accumulation was greater in faba bean than pea (Jensen, 1986c). Due to their indeterminate growth habit faba beans continued assimilating $\mathrm{N}$ for a longer period than pea, reaching about $315 \mathrm{~kg} \mathrm{~N} \mathrm{ha}^{-1}$ after 110 days. The $\mathrm{N}$ concentration in the faba bean crop biomass was around $5 \%$ a few days before flowering; during the initial stages (c. 30 days) of reproductive growth the $\mathrm{N}$ concentration declined rapidly to c. $2.5-3 \%$, due to the biomass accumulation rate being faster than the $\mathrm{N}$ assimilation rate, and the $\mathrm{N}$ concentration remained at this level until maturity (Jensen, 1986c). Faba bean accumulates $\mathrm{N}$ from $\mathrm{N}_{2}$ fixation at an increasing rate until initiation of the maturation process unless other factors such as water availability restricts the $\mathrm{N}_{2}$ fixation process earlier in growth.

\subsection{Nitrogen requirement during early growth}

Large seed cultivars of faba bean may contain up to $10 \mathrm{~kg} \mathrm{~N} \mathrm{ha}^{-1}$ in their seed reserves, when sown at a population of 40 seeds $\mathrm{m}^{-2}$ and this $\mathrm{N}$ is important for supporting early growth until nodules are formed and functioning c. 10-12 days after seedling emergence. Especially in soils low in mineral N, Jensen et al (1985a) observed that the seed $\mathrm{N}$ was equally distributed between roots and leaves during the first weeks of growth. There has been some controversy about the requirement for sowing grain legumes with low levels of "starter N" to overcome N-limitations during early growth stages, but a positive yield response is seldom observed if the soil contains $>20-30 \mathrm{~kg} \mathrm{~N} \mathrm{ha}^{-1}$ in the plough-layer (Richards and Soper, 1982; Jensen, 1986c).

\subsection{Acquisition of soil mineral $\mathbf{N}$}

In natural ecosystems legumes are often found in habitats with low levels of soil mineral $\mathrm{N}$ either because soil organic matter is low (environments for pioneer species) or because nonlegumes compete strongly with the legumes in mixed plant communities. When soil mineral $\mathrm{N}$ is present faba bean will utilize this source of N. Patriquin (1986) found that faba bean was capable of acquiring substantial amounts of soil mineral $\mathrm{N}\left(280 \mathrm{~kg}\right.$ soil $\left.\mathrm{N} \mathrm{ha}^{-1}\right)$ from a sandy clay loam in Nova Scotia and suggested that a large part of this mineral $\mathrm{N}$ was extracted by faba bean's tap- 
roots from relatively deep soil layers. Table 2 presents examples of estimates soil mineral $\mathrm{N}$ uptake ranging from 3 to $276 \mathrm{~kg} \mathrm{~N}^{-1}$ depending on growth conditions. A major part of the soil mineral $\mathrm{N}$ may have been used more efficiently if the faba bean was intercropped with a nonlegume.

Adding $50 \mathrm{~kg} \mathrm{~N}$ ha ${ }^{-1}$ labelled with the "heavy" stable-isotope ${ }^{15} \mathrm{~N}$ to follow the fate of the inorganic soil $\mathrm{N}$ pool showed that faba bean had a slower uptake of the mineral $\mathrm{N}$ than either pea or spring barley until full bloom (Fig. 5; Jensen, 1986c). At maturity faba bean had also recovered less fertilizer $\mathrm{N}$ than both pea and spring barley. Since the estimated soil $\mathrm{N}$ uptake is partly based on the recovery of fertilizer, estimates of soil $\mathrm{N}$ uptake was similarly lower in faba bean than in peas and spring barley, despite the longer growth period (Fig. 5). Faba bean compensated for the lower fertilizer and soil $\mathrm{N}$ uptake by a greater $\mathrm{N}_{2}$ fixation compared to the pea cultivars (Fig 5.). Smith et al. (1987) and Rennie and Dubetz (1986) also reported that faba bean was less efficient in recovering ${ }^{15} \mathrm{~N}$-labelled fertilizer from soil than other grain legumes and cereals. The explanation for the lower $\mathrm{N}$-fertilizer utilization in faba bean compared to other 508

\subsection{Symbiotic $\mathbf{N}_{2}$ fixation in faba bean}

The amount of $\mathrm{N}_{2}$ fixed by the symbiotic relationship between faba bean and the soil bacteria rhizobia is determined by the relative reliance of the crop upon $\mathrm{N}_{2}$ fixation for growth (i.e. the proportion of the crop $\mathrm{N}$ derived from atmospheric $\mathrm{N}_{2}$, \%Ndfa) and the amount of $\mathrm{N}$ accumulated by the crop over the growing season. There is sufficient capacity for biological $\mathrm{N}_{2}$ fixation to supply the majority of the faba bean $\mathrm{N}$ requirements for growth and field data indicate that $\mathrm{N}_{2}$ fixation can support the accumulation of 10-15 t shoot dry matter (DM) per ha (e.g. Rochester et al., 1998). However, the formation of a working symbiosis between legume and rhizobia is dependent upon many environmental factors and management practices, so it cannot be assumed that it will occur as a matter of course. This is reflected in the range of experimental estimates of \%Ndfa and amounts of $\mathrm{N}_{2}$ fixed by faba bean and other legume crops growing in different parts of the world (Tables 2 and 3). Yet despite the measures of \%Ndfa ranging from close to zero to almost $100 \%$ in some instances, there were marked similarities in the mean estimates of \%Ndfa within a species across geographic regions (Table 3). There also appeared to 
be distinct differences between faba bean and the other legume species in their capacity for $\mathrm{N}_{2}$ fixation, with faba bean having a higher reliance upon $\mathrm{N}_{2}$ fixation for growth and fixing larger amounts of N (Table 3). Hardarson and Atkins (2003) came to the same general conclusion based on data collated from a series of FAO/IAEA co-ordinated research programmes undertaken in different countries around the world. Similar differences between faba bean and alternative cool-season legume crops are also apparent in the \%Ndfa and $\mathrm{N}_{2}$ fixation data collected from commercial crops growing in Australia (Table 4).

Although the levels of \%Ndfa are important, provided there are adequate numbers of effective rhizobia in the soil in which the legume is growing and concentrations of soil mineral $\mathrm{N}$ are not too high, $\mathrm{N}_{2}$ fixation will generally be regulated by faba bean growth rather than by \%Ndfa (Peoples et al., 2009a). Limited data collected from commercial faba bean crops suggest that about $2 \mathrm{t}$ shoot DM per ha was required before substantial $\mathrm{N}_{2}$ fixation was evident, but over the total range of shoot biomass measured (2-12 t DM ha ${ }^{-1}$ ) around $22 \mathrm{~kg}$ shoot $\mathrm{N}$ was fixed, on average, for every tonne of shoot DM produced (Rochester et al., 1998).

The \%Ndfa of a legume is not a characteristic determined by a legume genotype and rhizobia alone, but reflects the interaction between plant-available soil $\mathrm{N}$ and legume growth (Unkovich and Pate, 2000). Soil mineral $\mathrm{N}$ and $\mathrm{N}_{2}$ fixation are complementary in meeting the $\mathrm{N}$ requirements for growth by a food legume crop, and the inhibitory effect of nitrate on nodulation and $\mathrm{N}_{2}$ fixation processes is well documented. High levels of soil nitrate, induced by such factors as excessive tillage, long fallows, applications of fertilizer $\mathrm{N}$ and extended legume rotations, are all known to delay the formation of nodules and the onset of $\mathrm{N}_{2}$ fixation and to reduce \%Ndfa, and the amount of $\mathrm{N}_{2}$ fixed by faba beans and other legumes (e.g. Schwenke et al., 1998; Peoples et al., 2001). High levels of soil mineral N may have a detrimental effect on the yield of faba bean, since high levels of mineral $\mathrm{N}$ will delay nodulation and if nodules are not well established at the time of the highest $\mathrm{N}$ demand during flowering and early pod-fill then $\mathrm{N}$ may temporarily be limiting growth and the final grain yield. Strategies that reduce soil mineral $\mathrm{N}$ availability to faba bean include sowing faba bean following a cereal or some other N-hungry crop, and increased competition for plant-available soil $\mathrm{N}$ such as intercropping legumes with cereals as discussed in section 2.3 (Hauggaard-Nielsen et al., 2008; Li et al., 2009). LopezBellido et al. (2006) compared the effects of no-till and conventional tillage on $\mathrm{N}_{2}$ fixation, but 
found no significant difference between treatments. However, no major difference in the soil nitrate dynamics was observed between the different tillage methodologies in this particular experiment, and this could explain the lack of response.

Data collected from rain-fed commercial faba bean crops in the northern cropping zone of eastern Australia suggested the critical value of soil nitrate present at sowing in the crop rooting zone that totally inhibits $\mathrm{N}_{2}$ fixation may be greater than $150-200 \mathrm{~kg}$ nitrate- $\mathrm{N} \mathrm{ha}^{-1}$ (Fig. 6; Schwenke et al., 1998). While these on-farm results may have been complicated by low rainfall conditions, it was illuminating to note that neighboring chickpea crops, sampled as part of the same survey, had much lower levels of \%Ndfa than faba bean at equivalent concentrations of soil nitrate (Fig. 6). Data from experimental trials also led Turpin et al. (2002) to conclude that faba bean can maintain a higher dependence on $\mathrm{N}_{2}$ fixation for growth and fix more $\mathrm{N}$ than chickpea under the same soil N supply (Fig. 7). Herridge et al. (2008) calculated a global estimate of the total amount of $\mathrm{N}_{2}$ fixed by faba bean to be in the order of 290,000 $\mathrm{t} \mathrm{N}$ each year out of around 22 million $\mathrm{N}$ by all grain legume crops including soybean.

\subsection{Rhizodeposition of $\mathbf{N}$ and soil $\mathbf{N}$ balances}

Senescent leaves that are dropped as faba bean reaches maturity may contain up to $90 \mathrm{~kg} \mathrm{~N} \mathrm{ha}^{-1}$, and the shoot residues remaining after grain harvest can represent substantial amounts of $\mathrm{N}$ (Patriquin, 1986). Faba bean has been reported to withdraw substantially more $\mathrm{N}$ from the soil in the grain than it contributed through inputs of fixed $\mathrm{N}_{2}$ resulting in a negative soil $\mathrm{N}$ balance (Patriquin, 1986), but other studies have suggested the opposite (e.g. Rochester et al., 1998). The general conclusions drawn by researchers about whether faba bean cropping is likely to provide a net contribution of fixed $\mathrm{N}$ to the soil, or result in a net depletion of soil $\mathrm{N}$, is strongly dependent on the estimate of total $\mathrm{N}_{2}$ fixation and whether the potential inputs of fixed $\mathrm{N}$ associated with, or derived from the nodulated roots are included or not in $\mathrm{N}$ balance calculations (Peoples et al., 2001).

The rhizodeposition of legume $\mathrm{N}$ is constituted by root exudates, sloughed cells and root nodules during plant growth, and the decomposition and mineralization of the complete root system following crop maturity (Wichern et al., 2008). The quantitative role of faba bean $\mathrm{N}$ rhizodepositions have been studied in some detail during the past decade (Rochester et al., 1998; 
Khan et al., 2002; Mayer et al., 2003a; Mayer et al., 2003b) and estimates range from 14 to 39\% of total plant $\mathrm{N}$. This has been calculated to represent up to $100 \mathrm{~kg} \mathrm{~N} \mathrm{ha}^{-1}$ of additional $\mathrm{N}$ being deposited below-ground (Rochester et al., 1998; Schwenke et al., 1998; Walley et al., 2007; Hauggaard-Nielsen et al., 2009). However, other researchers suggest a much lower net effect of rhizodeposition on the soil $\mathrm{N}$ balance ( $<27 \mathrm{~kg} \mathrm{~N} \mathrm{ha}^{-1}$; Evans et al., 1991). High levels of rhizodeposition will improve the soil $\mathrm{N}$ balance, assist in maintaining soil organic fertility, and appear to provide an important source of $\mathrm{N}$ for following crops in the rotation (Table 5). The duration between faba bean harvest and sowing the next crop, the turnover rate of above and below-ground legume $\mathrm{N}$ in soil, the timing of the requirement for $\mathrm{N}$ by the subsequent crop in relation to the supply of plant-available forms of $\mathrm{N}$, and the prevailing climatic conditions are all factors that will influence the efficiency with which $\mathrm{N}$ derived from legume residues will either be utilized for the growth of a following crop, or be lost from the plant-soil system (Peoples et al., 2004; Crews and Peoples, 2005).

\subsection{Losses of $\mathbf{N}$ by leaching and denitrification}

It is frequently observed that the level of soil mineral $\mathrm{N}$ is greater after harvesting grain legumes than after cereals. The enhanced level of soil mineral in the autumn may constitute a risk of enhanced nitrate leaching and denitrification in some regions. Soils sampled to $80 \mathrm{~cm}$ depth on 12 German farms following cultivation of faba bean, pea or winter wheat, showed about twice the levels of soil mineral $\mathrm{N}$ after grain legumes compared to wheat (Maidl et al., 1991). Later in the autumn the maximum value of soil mineral $\mathrm{N}$ was found to be 120,140 and $65 \mathrm{~kg} \mathrm{~N} / \mathrm{ha}$ after faba bean, pea and winter wheat, respectively. The lower C:N ratio of pea residues (21:1) than in faba bean (27:1) was suggested to cause a higher net $\mathrm{N}$ mineralization after pea (Maidl et al., 1991). A major proportion of the mineral soil $\mathrm{N}$ accumulated in the autumn can be lost by leaching during the winter from bare soil. In lysimeter experiments Hauggaard-Nielsen et al. (2009) found that the leaching in autumn and winter after faba bean, pea and oat (oat was not fertilized with $\mathrm{N}$ ) were 24, 29 and $15 \mathrm{~kg} \mathrm{~N} \mathrm{ha}^{-1}$, respectively. Autumn-established catch crops such as oil radish (Raphanus sativus L.) and white mustard (Sinapis alba L.) or winter oil seed rape showed that these crops recovered almost all the soil mineral N (Maidl et al., 1991). The biochemical nature of the catch crop material will greatly determine the proportion of faba bean 
derived $\mathrm{N}$ that will be subsequently mineralized in the next growing season (Thorup-Kristensen et al., 2003). Hauggaard-Nielsen et al. (2009) observed that a grass-clover catch crop after faba bean took up a major part of the available $\mathrm{N}$ which then remained immobilized over the following autumn and winter, due to the $\mathrm{C}: \mathrm{N}$ ratio of the catch crop biomass.

Very limited data are available on the effects of faba bean on annual denitrification rates. It is generally hypothesized that the greater residue $\mathrm{N}$ concentrations and enhanced soil mineral $\mathrm{N}$ availability in the autumn are likely to enhance the risk of denitrification (Crutzen et al., 2007). However, the concentration of soil nitrate alone may not be a valid predictor of denitrification (Rochette et al., 2004). The proportion of the total emissions of denitrified $\mathrm{N}$ as greenhouse gas $\mathrm{N}_{2} \mathrm{O}$ as compared to $\mathrm{N}_{2}$, which is environmentally benign is also very important (Peoples et al., 2004). The ratio of $\mathrm{N}_{2} \mathrm{O}: \mathrm{N}_{2}$ emitted during denitrification is subject to many variables (Peoples et al., 2009b). For example, Kilian and Werner (1996) found that the mean denitrification increased four-fold in plots of $\mathrm{N}_{2}$-fixing faba bean compared to non-nodulated faba bean, perennial ryegrass (Lolium perenne L.) and oilseed rape. However, the data also indicated that much of this enhanced denitrification led to the end product $\mathrm{N}_{2}$ rather than $\mathrm{N}_{2} \mathrm{O}$ (Kilian and Werner, 1996).

\subsection{Effects of faba bean on subsequent crop performance}

Faba bean can improve the economic value of a following crop by enhancing the yield and/or increasing the protein concentration of the grain (e.g. Lopez-Bellido et al., 1998). Increased concentrations of inorganic $\mathrm{N}$ in the soil profile after faba bean cropping and increased $\mathrm{N}$ uptake by subsequent crops can result from "spared N" remaining in the soil as a result of a relatively inefficient recovery of soil mineral N compared to other crops (Fig. 7; Turpin et al., 2002), the release of $\mathrm{N}$ mineralized from above- and below-ground residues, and/or from the impact of the labile legume $\mathrm{N}$ on the balance between gross mineralization and immobilization processes undertaken by the soil microbial biomass (Rochester et al., 2001; Peoples et al., 2009a). Few studies have attempted to ascertain the relative importance of each of these pathways of $\mathrm{N}$ supply. Evans et al. (1991) used a multiple regression method to deduce that the soil mineral $\mathrm{N}$ remaining at harvest of a grain legume can be of greater significance in determining the residual $\mathrm{N}$ effect in wheat than the $\mathrm{N}$ in crop residues. 
The impact of faba bean on the $\mathrm{N}$ dynamics of following crops is well documented. For example, the residual $\mathrm{N}$ benefit to a winter wheat from a previous spring-sown faba bean was found to represent a savings of $30 \mathrm{~kg}$ fertilizer $\mathrm{N} \mathrm{ha}^{-1}$ compared to a wheat-wheat sequence (McEwen et al., 1989). A Canadian five cycle rotation-study comparing a faba bean-barleywheat and a barley-barley-wheat rotation showed that faba bean enhanced the average yield in the subsequent barley and wheat crops by 21 and 12\%, respectively, which was equivalent to providing the cereals with around $120 \mathrm{~kg} \mathrm{~N}$ ha $^{-1}$ of $\mathrm{N}$ fertilizer (Wright, 1990). Rochester et al. (2001) observed that the optimum $\mathrm{N}$ fertilizer rate required to be applied to cotton following non-legume rotation crops was on average $180 \mathrm{~kg} \mathrm{~N} \mathrm{ha}^{-1}$, whereas after sequences including 652 either faba bean, soybean or pea the requirement was only c. $90 \mathrm{~kg} \mathrm{~N} \mathrm{ha}^{-1}$. Later studies indicated 653 almost a 50\% improvement in cotton lint yield after faba bean compared to other cropping sequences in the absence of additional fertilizer $\mathrm{N}$, with the non-legume rotations requiring rates of 150-200 kg fertilizer $\mathrm{N} \mathrm{ha}^{-1}$ before equivalent yield levels to those achieved following faba bean could be attained (Peoples et al., 2009a).

The few studies which have directly followed the fate of faba bean $\mathrm{N}$ using ${ }^{15} \mathrm{~N}$-labeled 659 660 661 662 663 664 665 666 667 668 669 670 671 672 residues indicate that a following wheat, barley or cotton crop may recover between $11-17 \%$ of the plant $\mathrm{N}$ remaining after faba bean, although this may represent only $2-19 \%$ of the total $\mathrm{N}$ requirement of those following crops (Muller and Sundman, 1988; Peoples et al., 2009a). However, studies that estimate uptake efficiencies of labeled $\mathrm{N}$ from recently applied legume residues can underestimate the overall N-supplying capacity of a legume-based system. This is demonstrated in the data from an Australian field-study where the $\mathrm{N}$ dynamics of a faba beanwheat cropping sequence was compared with barley-wheat presented in Table 5 . In this case when the additional $\mathrm{N}$ accumulated by the wheat grown after the faba bean was compared to wheat following barley the apparent recovery of legume $\mathrm{N}$ (40\%) was calculated to be 4-fold higher than indicated from the wheat's direct recovery of faba bean ${ }^{15} \mathrm{~N}$ ( $11 \%$ total; $3 \%$ from faba bean's above-ground residues, and 8\% derived from a below-ground pool associated with $\mathrm{N}$ from the nodulated roots and rhizodeposition, Table 5). Such differences appear to be the result of $\mathrm{N}$ 'pool substitution' whereby the newly applied ${ }^{15} \mathrm{~N}$-labeled legume $\mathrm{N}$ is preferentially immobilized in the microbial biomass, and older (unlabeled) soil organic $\mathrm{N}$ is mineralized and subsequently becomes available for crop uptake (Peoples et al., 2009a). The net result of such processes is that 
calculations based on direct crop recovery of ${ }^{15} \mathrm{~N}$-labeled leguminous material are often lower than the total benefits to the soil $\mathrm{N}$ dynamics derived from including a legume in a rotation.

Despite the above discussion, one should be cautious in necessarily attributing all such improvements in crop performance after faba bean to solely improvements in $\mathrm{N}$ availability. Faba bean can also provide a range of other potential rotational benefits that are not directly related to $\mathrm{N}$ such as reductions in the incidence of grassy weeds, reductions in diseases or pests, improvements in soil structure, or carry-over of available soil water (Rochester et al., 2001; Kirkegaard et al., 2008; Peoples et al., 2009a, Peoples et al., 2009b). Faba bean is known to be able to break soil-borne disease cycles within cereals such as take-all (Gaeumannomyces graminis), and the effect appears to be similar to the effect of other legume and non-legume break-crops (McEwen et al., 1989).

Legumes in rotations also generally result in greater microbial activity and diversity in soils (Lupwayi and Kennedy, 2007). Some of these changes in the composition of the microbial population in the legume's rhizosphere may be related to the release of molecular hydrogen $\left(\mathrm{H}_{2}\right)$ as a by-product of symbiotic $\mathrm{N}_{2}$ fixation in legume nodules (Dong et al., 2003).

About 35\% of the energy consumed in the overall nitrogenase activity goes towards $\mathrm{H}_{2}$ production (Hunt and Layzell, 1993). In some legume systems, the rhizobial bacteria possess a hydrogenase uptake enzyme system within the nodule (designated Hup ${ }^{+}$) that is able to recycle almost all of the $\mathrm{H}_{2}$ evolved and recover most of the energy that might otherwise be lost. However, the $\mathrm{Hup}^{+}$trait appears to be rare in legumes nodulated by strains of Rhizobium, Sinorhizobium, or Mesorhizobium spp., and the $\mathrm{H}_{2}$ produced in Hup symbioses (i.e. those legume $\mathrm{x}$ rhizobia combinations that lack a hydrogenase uptake system) diffuses out of the nodules into the soil (Evans et al., 1988; Hunt and Layzell, 1993). Experimentation undertaken in Australia to assess the Hup status of different nodulated legumes suggested that all the faba bean $\mathrm{x}$ rhizobial strain treatments examined were Hup ${ }^{-}$and the faba bean nodules exhibited much higher rates of $\mathrm{H}_{2}$ evolution from symbioses formed with any of the eight rhizobial strains tested (153-335 $\mu \mathrm{mol}$ $\mathrm{H}_{2}$ per g nodule dry weight per hour, average of $224 \mu \mathrm{mol} \mathrm{H}_{2}$ per g nodule dry weight per hour) than when the same strains were tested on lentil or pea (average of 48 and $60 \mu \mathrm{mol} \mathrm{H}_{2}$ per $\mathrm{g}$ nodule dry weight per hour, respectively; Peoples et al., unpublished data). Rates of $\mathrm{H}_{2}$ evolution from faba bean nodules were also higher than from chickpea symbioses (average of $86 \mu \mathrm{mol} \mathrm{H}_{2}$ 
per g nodule dry weight per hour), but were similar to emissions from lupin nodules (average of $278 \mu \mathrm{mol} \mathrm{H}_{2}$ per g nodule dry weight per hour). Other research has demonstrated that the exposure of soil to $\mathrm{H}_{2}$ results in an increase in Actinomycete species and other $\mathrm{H}_{2}$-oxidizing bacteria (Maimaiti et al., 2007; Osborne et al., 2009). The net result is that within 10-14 days after the initial exposure to $\mathrm{H}_{2}$ all of the $\mathrm{H}_{2}$ emitted is consumed and none escapes from the soil surface (Dong et al., 2003; Osborne et al., 2009). There appears to be substantial consequences of the $\mathrm{H}_{2}$ emissions, and its uptake by the soil microflora, on the soil and experiments undertaken both under controlled growth conditions and in the field have pointed to improvements in plant productivity in soils previously exposed to $\mathrm{H}_{2}$ (e.g. Dong et al., 2003; Dean et al., 2006; Peoples et al., 2008). Therefore, it could legitimately be speculated that the changes expected to be induced in soil microbial populations in response to the generally higher emissions of $\mathrm{H}_{2}$ from faba bean nodules would be beneficial for following crops.

Some or all of the factors discussed above could potentially contribute to more prolific and extensive root growth or overall enhanced growth potential by a following crop that might result in increased uptake of $\mathrm{N}$ and other nutrients from the soil. The true extent of the residual $\mathrm{N}$ effect of faba bean on a subsequent crop is probably best determined by comparing faba bean with other pre-crop treatments likely to provide similar non-N-benefits through their suppression of diseases, pests and weeds as faba bean. For example, when undertaking an experiment to estimate how much of faba bean's rotational impact on wheat was specifically derived from $\mathrm{N}$ it would be preferable to include another broadleaf species such as a brassica crop as a control rather than, or in addition to, the more commonly used continuous wheat-wheat or barley-wheat sequences which tend to favor the build-up of cereal-pathogens rather than diminish them as would be the case with the faba bean or brassica crops. Unfortunately few such studies have been undertaken, but it is clear that the choice of pre-crop species used for comparative purposes could influence the size of the presumed $\mathrm{N}$ benefits simply because the observed improvements in productivity of following crops may be confounded by effects of faba bean on factors other than $\mathrm{N}$. 


\section{Conclusions}

733

734

735

736

737

738

739

740

741

742

743

744

745

746

747

748

749

750

751

752

753

754

755

756

757

758

Faba bean has three main functions in an arable cropping systems: 1) the contribution protein rich food and feed, 2) supplying $\mathrm{N}$ to the system via symbiotic $\mathrm{N}_{2}$ fixation, and 3) diversifying the cropping system to reduce constraints to the growth and yield by other crop species in the rotation. To enhance the benefits of faba bean in the context of a future, more sustainable agriculture with less dependence on fossil energy, it is essential to stimulate research which aims at eliminating the yield instability of faba bean, to maximize its rotational benefits, and to determine, and eventually minimize or prevent, the risk of faba bean cropping having unwanted effects on the environment.

\section{References}

Amager, N. 1986. Nodulation competition among Rhizobium leguminosarum strains. Vortr. Pflanzenzücht 11, 186-194.

Bond, D.A., Lawes, G.C., Saxena, M.C. and Stephens, J.S.. 1985. Faba Bean (Vicia faba L.). In: Summerfield, R.J. and Roberts, E.H. (Eds.), Grain Legume Crops. William Collins Sons Co., London, UK, pp. 199-265.

Bolland, M.D.A., Siddique, K.H.M., Loss, S.P. and Baker, M.J. 1999. Comparing responses of grain legumes, wheat and canola to applications of superphosphate. Nutr. Cycl. Agroecosyst. $53,157-175$.

Bulson, H.A.J, Snaydon, R.W. and Stopes, C.E. 1997. Effects of plant density on intercropped wheat and field beans in an organic farming system. J. Agric. Sci. 128, 57-71.

Brockwell, J., Bottomley, P.J. and Thies, J.E. 1995. Manipulation of rhizobia microflora for improving legume productivity and soil fertility: a critical assessment. Plant Soil 174, 143-180. 
771

772

773

774

775

776

777

778

779

780

781

782

783

784

785

786

787

788

Carter, J.M., Gardner, W.K. and Gibson, A.H. 1994. Improved growth and yield of faba bean (Vicia faba cv. Fiord) by inoculation with strains of Rhizobium leguminosarum bv. viciae in acid soils in South-west Victoria. Aust. J. Agric. Res. 45, 613-623.

Choi, E., McNeill, A., Coventry, D. and Stangoulis, J. 2006. Whole plant response of crop and weed species to high subsoil boron. Austr. J. Agric. Res. 57, 761-770.

Crépon, K., Marget, P., Peyronnet, C., Carrouée, B., Arese, P., Duc, G., this issue. Nutritional value of faba bean (Vicia faba L.) seeds for feed and food. Field Crops Research, this issue

Crews, T.E. and Peoples, M.B. 2004. Legume versus fertilizer sources of nitrogen: Ecological tradeoffs and human needs. Agric. Ecosyst. Env. 102, 279-297.

Crews, T.E. and Peoples, M.B. 2005. Can the synchrony of nitrogen supply and crop demand be improved in legume and fertilizer-based agroecosystems? A review. Nutr. Cycl. Agroecosys. 72, 101-120.

Crozat, Y. and Fustec, J. 2006. Assessing the role of grain legumes in crop rotation: some agronomical concepts that can help. In: Schneider, A. and Craig, J. (Eds.), Grain Legumes and the environment: How to assess benefits and impacts? Agroscope FAL Reckenholz and AEP, Zurich, Switzerland. pp. 55-60.

Crutzen, P.J., Mosier, A., Smith, K.A. and Winiwarter, W. 2007. $\mathrm{N}_{2} \mathrm{O}$ release from agro-biofuel production negates global warming reduction by replacing fossil fuels. Atmos. Chem. Phys. Discuss. 7, 11191-11205.

Cubero, J.I. 1981. Vicia faba in Spain. Fabis 1, 10-11.

Dean, C.A., Sun, W., Dong, Z. and Caldwell, C.D. 2006. Soybean nodule hydrogen metabolism affects soil hydrogen uptake and the growth of rotation crops. Can. J. Plant Sci. 86, 1355-1359. 
De Wit, C.T. and Van den Bergh, J.P., 1965. Competition between herbage plants. Neth. J. Agr.

Dong, Z., Wu, L., Kettlewell, B., Caldwell, C.D. and Layzell, D.B. 2003. $\mathrm{H}_{2}$ fertilization of soils 794 - is this a benefit of leguminous in rotation? Plant Cell Environ. 26, 1875-1879.

795

796

797

Duke, J.A. 1981. Handbook of legumes of world economic importance. Plenum Press, New York. pp. 199-265.

798

799

800

Evans, H.J., Russell, S.A., Hanus, F.J. and Ruiz-Argüeso, T. 1988. The importance of hydrogen recycling in nitrogen fixation by legumes. In: World Crops: Cool Season Food Legumes. 801 Summerfield, R.J., Kluwer Academic Publishers, Boston, MA., USA, pp. 777-791.

802

803

Evans, J., Fettell, N.A., Coventry, D.R., O’Connor, G.E., Walsgott, D.N., Mahoney, J. and 804 Armstrong, E.L. 1991. Wheat response after temperate crop legumes in South-Eastern Australia. 805 Aust. J. Agric. Res. 42, 31-43.

806

Fan, F., Zhang, F., Song, Y., Sun, J., Bao, X., Guo, T. and Li, L. 2006. Nitrogen fixation of faba 808 809 bean (Vicia faba L.) interacting with a non-legume in two contrasting intercropping systems. Plant Soil 283, 275-286.

810

811

FAOSTAT. 2008. http://faostat.fao.org/site/567/default.aspx\#ancor

812

813

814

Fernández-Aparicio, M., Sillero, J.C. and Rubiales, D. 2007. Intercropping with cereals reduces 815

816

817 infection by Orobanche crenata in legumes. Crop Prot. 26, 1166-1172.

818 
George, E., Kothari, S.K, Li, X.-L., Weber, E., Marschner, H. 1994. VA mycorrhizae: benefits to crop plant growth and costs. In: Muhlbauer, F.J. and Kaiser, W.J. (Eds.), Expanding the use of cool season food legumes, Kluwer Academic Publishers, The Netherlands. pp. 832-846.

822

Gooding, M.J., Kasynova, E., Ruske, R., Hauggaard-Nielsen, H., Jensen, E.S., Dahlmann, C., 824 Fragstein, P. von, Dibet, A., Corre Hellou, G., Crozat, Y., Pristeri, A., Romeo, M., Monti, M. 825 and Launay, M. 2007. Intercropping with pulses to concentrate nitrogen and sulphur in wheat. J. 827 Agric. Sci. 145, 469-479.

Green, C.F., Hebblethwaite, P.D. and Ricketts, H.E. 1986. Irrigating faba bean crops. Vortr. Pflanzenzücht 11, 7-24.

830

Hardarson, G. and C. Atkins. 2003. Optimizing biological $\mathrm{N}_{2}$ fixation by legumes in farming 832 systems. Plant Soil 252, 41-54.

833

Hauggaard-Nielsen, H., Jørnsgaard, B., Kinane, J. and Jensen, E.S. 2008. Grain legume - cereal 835 intercropping: The practical application of diversity, competition and facilitation in arable and 837 organic cropping systems. Renew. Agric. Food Sys. 23, 3-12.

Haynes, R.J., Martin, R.J. and Goh, K.M. 1993. Nitrogen fixation, accumulation of soil nitrogen 843 and nitrogen balance for some field-grown legume crops. Field Crops Res. 35, 85-92.

844

Herridge, D.F., Peoples, M.B. and Boddey, R.M. 2008. Marschner Review: Global inputs of 846 biological nitrogen fixation in agricultural systems. Plant Soil 311, 1-18. 
Hunt, S. and Layzell, D.B.. 1993. Gas exchange of legume nodules and the regulation of nitrogenase activity. Ann. Rev. Plant Physiol. Mol. Biol. 44, 483-511.

850

Jensen, E.S. 1986a. Intercropping field bean with spring wheat. Vortr. Pflanzenzücht. 11, 67-75.

852

853

Jensen, E.S. 1986b. Intercropping faba bean with maize in Denmark. Fabis 16, 25-28.

854

855

Jensen, E.S. 1986c. Symbiotic $\mathrm{N}_{2}$ fixation in pea and field bean estimated by ${ }^{15} \mathrm{~N}$ fertilizer 856 dilution in field experiments with barley as a reference crop. Plant Soil 92, 3-13.

857

858

859

Jensen, E.S. 1987. Inoculation of pea by application of Rhizobium in the planting furrow. Plant Soil 860

861

862

863

864 97, 63-70.

865

866

867

868

869

870

871

872

873

874

875

Jensen, E.S. (ed.) 2006. INTERCROP - Intercropping of cereals and grain legumes for increased production, weed control, improved product quality and prevention of N-losses in European organic farming systems. Final report. EC project QLK5-CT-2002-02352, Roskilde, Denmark, $302 \mathrm{p}$.

876

Jensen, E.S. and Hauggaard-Nielsen, H. 2003. How can increased use of biological $\mathrm{N}_{2}$ fixation in agriculture benefit the environment? Plant Soil 252, 177-186.

Jensen, E.S., Andersen, A.J. and Thomsen, J.D. 1985a. The influence of seed-borne $\mathrm{N}$ in ${ }^{15} \mathrm{~N}$ isotope dilution studies with legumes. Acta Agric. Scand. 35, 438-443.

Jensen, E.S., Andersen, A,J., Sørensen, H and Thomsen, J.D. 1985b Nitrogen supply from symbiotic nitrogen fixation. II. Symbiotic $\mathrm{N}_{2}$ fixation and $\mathrm{N}$ fertilization of grain legumes. Risø National Laboratory, Report Risø-M-2428. ISBN 87-550-1076-8. In Danish with summary in English, $91 \mathrm{p}$. 
893

894

895

896

897

898

899

900

901

902

903

904

905

Khan, D.F., Peoples, M.B., Chalk, P.M. and Herridge, D.F. 2002. Quantifying below-ground nitrogen of legumes. 2. A comparison of ${ }^{15} \mathrm{~N}$ and non-isotopic methods. Plant Soil 239, 277-289.

Khan, H.R., Paull. J.G., Siddique, K.H.M., Stoddard, F.L., this issue. Faba bean breeding for drought tolerance: a physiological and agronomic perspective. Field Crops Res., this issue

Kilian, S. and Werner, D. 1996. Enhanced denitrification in plots of $\mathrm{N}_{2}$-fixing faba beans compared to plots of a non-fixing legume and non-legumes. Biol. Fert. Soils 21, 77-83.

Kinane, J. and Lyngkjær, M. 2002. Effect of barley-legume intercrop on disease frequency in an organic farming system. Plant Protec. Sci. 38, 227-231.

Kirkegaard, J., Christen, O., Krupinsky, J. and Layzell, D. 2008. Break crop benefits in temperate wheat production. Field Crops Res. 107, 185-195.

Knudsen, M.T., Hauggaard-Nielsen, H. and Jensen, E.S. 2004. Pea, faba bean and lupin intercropped with spring barley - performance and $\mathrm{N}_{2}$ fixation at two temperate locations. J. Agric. Sci. 142, 617-627.

Li, Y-Y., Yu, C-B., Cheng, X., Li, C-J., Sun, J-H., Zhang, F-S., Lambers, H., Li, L. 2009. Intercropping alleviates the inhibitory effect of $\mathrm{N}$ fertilization on nodulation and symbiotic $\mathrm{N}_{2}$ fixation of faba bean. Plant Soil (in press).

Link, W., Balko, C, Stoddard, F.L., this issue. Winter hardiness in faba bean: physiology and breeding. Field Crops Res., this issue

Lopez-Bellido, L., Fuentes, M., Castillo, J.E. and Lopez-Garrido, F.J. 1998. Effects of tillage, crop rotation and nitrogen fertilization on wheat grain quality grown under rain-fed Mediterranean conditions. Field Crops Res. 57, 265-276.

Lopez-Bellido, L., Lopez-Bellido, R., Redondo, R. and Benitez J. 2006. Faba bean nitrogen 
906

907

908

909

910

911

912

913

914

915

916

917

918

919

920

921

922

923

924

925

926

927

928

929

930

931

932

933

934

935

fixation in a wheat-based rotation under rain-fed Mediterranean conditions: effect of tillage system. Field Crops Res. 98, 253-260.

Lopez-Bellido, R.J., Lopez-Bellido, L., Benitez-Vega, J. and Lopez-Bellido, F.J. 2007. Tillage system, preceding crop and nitrogen fertilizer in wheat crop: water utilization. Agron. J. 99, 6672.

Loss, S.P. and Siddique, K.H.M. 1997. Adaption of faba bean (Vicia faba L.) to dryland Mediterranean-type environments. I Seed and yield components. Field Crops Res. 52, 17-28.

Lupwayi, N.Z. and Kennedy, A.C. 2007. Grain legumes in Northern Great Plains: Impacts on selected biological soil processes. Agron. J. 99, 1700-1709.

Maidl, F.X., Suckert, J., Funk, R. and Fischbeck, G. 1991. Field studies on nitrogen dynamics after cultivation of legumes. J. Agron. Crop. Sci. 167, 259-268.

Maimaiti, J., Zhang, Y., Yang, J., Cen Y-P, Layzell D.B., Peoples, M. and Dong, Z. 2007. Isolation and characterization of hydrogen-oxidizing bacteria induced following exposure of soil to hydrogen gas and their impact on plant growth. Environ. Microbiol. 9, 435-444.

Martin, M.P.L.D. and Snaydon, R.W. 1982. Intercropping barley and beans: Effect of planting pattern. Exp. Agric. 18, 139-148.

Mayer, J., Buegger, F., Jensen, E.S., Schloter, M. and Hess, J. 2003a Estimating N rhizodeposition of grain legumes using a ${ }^{15} \mathrm{~N}$ in situ stem labelling method. Soil Biol. Biochem. 35, 21-28.

Mayer, J., Buegger, F., Jensen, E.S., Schloter, M. and Hess, J. 2003b Residual nitrogen contribution from grain legumes to succeeding wheat and rape and the microbial biomass. Plant Soil. 255, 541554. 
McEwen, J., Darby, R.J., Hewitt, M.V. and Yeoman, D.P. 1989. Effects of field beans, fallow, lupins, oats, oilseed rape, peas, ryegrass, sunflowers and wheat on nitrogen residues in the soil and on the growth of a subsequent wheat crop. J. Agric. Sci., Camb. 115, 209-219. materials during decomposition under field conditions. Plant Soil 105, 133-139.

Murinda, M.V. and Saxena, M.C. 1985. Agronomy of faba beans, lentils and chickpeas. In: M.C. Kabuli Chickpeas and Lentils in the 1980s. ICARDA, Aleppo, pp. 229-244.

Mytton, L.R., El-Sherbeeny, M.H. and Lawes, D.A. 1977. Symbiotic variability in Vicia faba. III. Genetic effects of host plant, Rhizobium strain and of host x strain interaction. Euphyt. 26, 950 785-791.

954

955

956

957

958

959

960

961

962

Nemecek, T., von Richthofen, J.-S., Dubois, G., Casta, P., Charles, R. and Pahl, H. 2008. Environmental impacts of introducing grain legumes into European crop rotations. Europ. J. Agronomy 28, 380-393.

Osborne, C.S., Peoples, M.B. and Janssen, P.H. (2009) Natural and simulated hydrogen exposure from legume root nodules enrichs for actinomycetes within the soil bacterial community. Appl. Envir. Microbiol. (submitted)

Pala, M., Saxena, M.C., Papastylianou, I. and Jaradat, A.A. 1994. Enhancing the use of cool season food legumes in different farming systems. In: Muhlbauer F.J. and Kaiser W.J. (Eds.), Expanding the use of cool season food legumes, Kluwer Academic Publishers, The Netherlands. pp. 130-143.

Pare, T., Chalifour, F.P., Bourassa, J. and Antoun, H.1993. The residual effects of faba bean and soybean for a $2^{\text {nd }}$ and $3^{\text {rd }}$ succeeding forage-corn production. Can. J. Plant Sci. 73, 495-507. 
Patriquin, D. 1986. Biological husbandry and the "nitrogen" problem. Biol. Agric. Hort. 3, 167189.

969

970

971

Peoples, M.B. and Herridge, D.F. 1990. Nitrogen fixation by legumes in tropical and subtropical

972

973

Peoples, M.B., Bowman, A.M., Gault, R.R., Herridge, D.F., McCallum, M.H., McCormick, 974 agriculture. Adv. Agron. 44, 155-223.

977

978

979

980

981

982

983

984

985

986

987

988

989

990

991

992 K.M., Norton, R.M., Rochester, I.J., Scammell, G.J. and Schwenke, G.D. 2001. Factors regulating the contributions of fixed nitrogen by pasture and crop legumes to different farming systems of eastern Australia. Plant Soil 228, 29-41.

Peoples, M.B., Boyer, E.W., Goulding, K.W.T., Heffer, P., Ochwoh, V.A., Vanlauwe, B., Wood, S., Yagi, K. and Van Cleemput, O. 2004. Pathways of nitrogen loss and their impacts on human health and the environment. In: Mosier, A.R., Syers, K.J. and Freney, J.R. (Eds.). Agriculture and the Nitrogen Cycle, The Scientific Committee on Problems of the Environment (SCOPE). Island Press, Covelo, California, USA. pp. 53-69.

993 
994 Peoples, M.B., McLennan, P.D., and Brockwell, J. 2008. Hydrogen emission from nodulated 995 soybeans [Glycine max (L.) Merr.] and consequences for the productivity of a subsequent maize 996 (Zea mays L.) crop. Plant Soil 307, 67-82.

997

998 Pérez-de-Luque, A., Eizenberg, H., Grenz, J.H., Sillero, J.C., Avila, C., Sauerborn, J., Rubiales, 999 D., this issue. Broomrape management in faba bean. This issue.

1000

1001

PGRO 2008. Pulse agronomy guide 2008. http://www.pgro.org/agronomy_guide/agron_guide.shtml

1002

1003

Poulain, D. and Al Mohammad, H. 1995. Effect of boron deficiency and toxicity on faba bean 1004 (Vicia faba L.). Eur. J. Agron. 4, 127-131.

1005

1006

Rennie, R.J. and Dubetz, S. 1986. Nitrogen-15-determined nitrogen fixation in field-grownchickpea, lentil, fababean and field pea. Agron. J. 78, 654-660.

1008

1009

Richards, J.E. and Soper, R.J. 1982. N fertilization of field-grown faba beans in Manitoba. Can. J. Soil. Sci. 62, 21-30.

1011

1012

Rochester, I.J., Peoples, M.B., Constable, G.A. and Gault, R.R. 1998. Faba beans and other 1013 legumes add nitrogen to irrigated cotton cropping systems. Aust. J. Exp. Agric. 38, 253-60

1014

1015

Rochester, I.J., Peoples, M.B., Hulugalle, N.R., Gault, R.R. and Constable, G.A. 2001. Using 1016 1017 legumes to enhance nitrogen fertility and improve soil condition in cotton cropping systems. 1018 Field Crops Res. 70, 27-41.

1021

Rochette, P., Angers, D.A., Bélanger, G., Chantigny, M.H., Prévost, D. and Lévesque, G. 2004. Emissions of $\mathrm{N}_{2} \mathrm{O}$ from Alfalfa and Soybean Crops in Eastern Canada. Soil Sci. Soc. Am. J. 68, 1022 493-506 
Saxena, M.C., Silim, S.N. and Murinda, M.V. 1986. Effect of moisture stress and fertilizer application on the yield build-up of some contrasting faba bean genotypes. Vortr. Pflanzenzücht. $11,40-48$.

Sebillotte, M. 1995. Analysing farming and cropping systems and their effects. Some operative concepts. In: Brossier, J., de Bonneval, L. and Landais, E. (Eds.) System studies in Agriculture and Rural Development, INRA, Paris, pp. 283-290.

Schmidtke, K. 2006. Effect of grain legumes on water-use efficiciency in crop rotations. In Grain Legumes and the Environment: How to assess benefits and impacts? In: Schneider, A. and Craig, J. (Eds.) AEP Workshop 18-19 November 2004, Zurich, Switzerland. pp. 61-66.

Schwenke, G.D., Peoples, M.B., Turner, G.L. and Herridge, D.F. 1998 Does nitrogen fixation of commercial, dryland chickpea and faba bean crops in north-west New South Wales maintain or enhance soil nitrogen? Aust. J. Exp. Ag. 38, 61-70.

Siddique, K.H.M., Regan, K.L., Tennant, D. and Tomson, B.D. 2001. Water use and water use efficiency of cool season grain legumes in low rainfall Mediterranean-type environments. Eur. J. Agron.15, 267-280.

Slinkard, A.E., Bascur, G., and Hernandez-Bravo, G. 1994. Biotic and abiotic stress of cool season food legumes in the western hemisphere. In: Muhlbauer F.J. and Kaiser W.J. (Eds.), Expanding the use of cool season food legumes. Kluwer Academic Publishers, The Netherlands. pp. 195-203.

Smil, V. 2001. Enriching the Earth. MIT Press, Cambridge, Massachusetts.

Smith, S.C., Bezdicek, R.F., Turco, R.F. and Cheng, H.H. 1987. Seasonal $\mathrm{N}_{2}$ fixation by coolseason pulses based on several ${ }^{15} \mathrm{~N}$ methods. Plant Soil 97, 3-13. 
Sparrow, S.D., Cochran, V. and Sparrow, E.B. 1995. Dinitrogen fixation by seven legume crops in Alaska. Agron. J. 87, 34-41.

Sprent, J.I. and Bradford, A.M. 1977. Nitrogen fixation in field beans (Vicia faba) as affected by population density, shading and its relationships with soil moisture. J. Agric. Sci. Cambridge. 88, 303-310. Agric. Sci. Cambridge. 88, 293-30

Stanforth, J.I., Sprent, J.I., Brockwell, J., Beck, D.P. and Moawad, H. 2004. Biological nitrogen fixation: basic advances and persistent agronomic constraints. In: Muhlbauer F.J. and Kaiser W.J. (Eds.), Expanding the use of cool season food legumes, Kluwer Academic Publishers, The Netherlands. pp. 821-831.

Stoddard F.L., Nicholas, A., Rubiales, D., Thomas, J., Villegas, A.M., this issue. Integrated pest management in faba bean. Field Crops Res., this issue. with the “erweitere differenzmethode”. J. Agron. Crop. Sci. 151, 446-458.

Tanaka, D.L., Krupinsky, J.M., Liebig, M.A., Merrill, S.D., Ries, R.E., Hendrickson, J.R., Johnson, H.A. and Hanson, J.D. 2002. Dynamic cropping systems: an adaptable approach to crop production in the Great Plains. Agron. J. 94, 957-961. 302. 
Turpin, J.E., Herridge, D.F., Robertson, M.J. 2002. Nitrogen fixation and soil nitrate interactions in field-grown chickpea (Cicer arietinum) and faba bean (Vicia faba). Aust. J. Agric. Res. 53, 599-608.

Unkovich, M.J. and Pate, J.S. 2000. An appraisal of recent field measurements of symbiotic $\mathrm{N}_{2}$ fixation by annual legumes. Field Crops Res. 65, 211-228.

Unkovich, M.J., Pate, J.S., and Sanford, P. 1997. Nitrogen fixation by annual legumes in Australian Mediterranean agriculture. Aust. J. Agric.Res. 48, 267-293.

Vandermeer, J. 1989. The Ecology of Intercropping. Cambridge University Press.

Walley, F.L., Clayton, G.W., Miller, P.R., Carr, P.M. and Lafond, G.P. 2007. Nitrogen economy of pulse crop production in the northern great plains. Agron. J. 99, 1710-1718.

Wani, S.P., McGill, W.B. and Robertson, J.A. 1991. Soil N dynamics and N yield of barley grown on Breton loam using N from biological fixation or fertilizer. Biol. Fertil. Soils 12, 10-18.

Wani, S.P., McGill, W.B., Haugenkozyra, K.L., Robertson, J.A. and Thurston, J.J. 1994. Improved soil quality and barley yields with faba-beans, manure, forages and crop rotation on a gray luvisol. Can. J. Soil Sci. 74, 75-84.

Wichern, F., Eberhardt, E., Mayer, J., Joergensen, R.G., Müller, T. 2008. Nitrogen rhizodeposition in agricultural crops: Methods, estimates and future prospects. Soil Biol. Biochem. 40, 30-48.

Willey, R.W., 1979. Intercropping - Its Importance and research Needs. Part 1. Competition and Yield Advantages. Field Crop Abstracts 32, 1-10. 
1106 Witty, J. F. 1983. Estimating $\mathrm{N}_{2}$ fixation in the field using ${ }^{15} \mathrm{~N}$-labelled fertilizer; some problems 1107 and solutions. Soil Biol. Biochem. 15, 631-639.

1108

Wright, A.T. 1990. Yield effect of pulses on subsequent cereal crops in the northern prairies.

1110 Can. J. Plant Sci. 70, 1023-1032.

1111

Zhang, F., Shen, J., Li, L. and Liu, X. 2004. An overview of rhizosphere processes related with 1113 plant nutrition in major cropping systems in China. Plant Soil 260, 89-99.

1114

Zohary, D. and Hopf, M. 2000. Domestication of plants in the Old World. $3^{\text {rd }}$ Edn., 316 pp., 1116 Oxford University

1117 


\section{Figure legends}

1119

1120

1121

1122

1123

1124

1125

1126

1127

1128

1129

1130

1131

1132

1133

1134

1135

1136

1137

1138

1139

1140

1141

1142

1143

1144

1145

Fig. 1. Proportion of faba bean in arable cropping systems in selected countries (a) China and Egypt, (b) Australia, Canada, France and UK (FAOSTAT, 2008)

Fig. 2. Development of faba bean grain yield in selected countries. (a) China, Egypt and France, (b) Australia, Canada and UK (FAOSTAT, 2008).

Fig. 3. Average (a) grain dry matter (DM) yields and (b) above-ground $\mathrm{N}$ accumulation of sole cropped pea (cv. Agadir), faba bean (cv. Columbo) and the two barley cultivars A (cv. Otira) and B (cv. Lysiba) grown in a sandy loam soil during 2001-2003 as compared to the respective dual $50 \%+50 \%$ (replacement design) cereal-legume intercrops. Land equivalent ratio (LER) using grain yield data are given on top of the intercrop bars (a). Total above-ground $\mathrm{N}$ accumulation is partitioned in soil $\mathrm{N}$ and leguminous symbiotic $\mathrm{N}_{2}$ fixation using the ${ }^{15} \mathrm{~N}$ natural abundance technique. Percentage of leguminous $\mathrm{N}$ originated from fixation is given on the top of bars (b). $\mathrm{LSD}_{0.05}$ between total values of the cropping strategies is given by floating bars. Modified from Hauggaard-Nielsen et al. (2008)

Figure 4 Faba bean (cv. Columbo), pea (cv. Agadir), lupin (angustifolius; cv. Prima) and barley (cv. Otira) grain dry matter (DM) when grown as sole crops (SC) at recommended sowing densities as compared to intercrop (IC) designs with dual (IC2 $=50 \%+50 \%$ ), triplicate (IC3 = $33.3 \%+33.3 \%+33.3 \%$ ) or quadruple (IC4 $=25 \%+25 \%+25 \%+25 \%$ ) replacement designs assuming that the interactions between intercrop components are not confounded by alterations in the relative plant density in the intercropping compared to sole cropping (De Wit and van der Bergh, 1965). The study was conducted on a temperate sandy loam soil in 2002. Values are the mean $(n=4)$ and columns with the same letter on top within each individual diagram are not significantly different using Tukey's Studentized Range (HSD) Test for treatments. Land equivalent ratio (LER) using the respective grain yield parameters are given on top of the intercrop bars (unpublished data). Open columns: faba bean yield, filled columns: sum of other IC components. 
Fig. 5. Above-ground $\mathrm{N}$ accumulated from (a) fertilizer $\mathrm{N}$ (50 kg N ha ${ }^{-1},{ }^{15} \mathrm{~N}$-labelled), (b) soil $\mathrm{N}$ and (c) atmospheric $\mathrm{N}_{2}$ in spring-sown faba bean (cv. Diana), a determinate white-flowered pea cultivar A (cv. Bodil), an indeterminate purple-flowered pea cultivar B (cv. Timo) and spring barley (cv. Nery) determined at full bloom/anthesis (open column) and maturity (closed column). The numbers in the top of the columns in diagram (a) represent fertilizer recovery while the percentage of shoot $\mathrm{N}$ derived from $\mathrm{N}_{2}$ fixation are indicated at the top of the columns in diagram (c). The values are the mean of three years field experiments \pm SE. Modified from Jensen et al. (1986c).

Fig. 6. The impact of concentrations of available soil $\mathrm{N}$ at sowing on plant reliance upon $\mathrm{N}_{2}$ fixation for growth (\%Ndfa) by farmers' (a) chickpea and (b) faba bean crops in Australia (modified from Schwenke et al., 1998)

Fig. 7. Comparison of the amounts of soil $\mathrm{N}$ and $\mathrm{N}_{2}$ fixed accumulated at crop maturity by (a) chickpea and (b) faba bean growing in soils of differing $\mathrm{N}$ fertility. Estimates of soil $\mathrm{N}$ supply was determined by the uptake of $\mathrm{N}$ by wheat growing in the same soils (derived from data presented by Turpin et al. 2002). Note that for each of the 3 soils examined the amounts of soil $\mathrm{N}$ estimated to have been recovered by the legumes (closed portion of each histogram) were substantially less than the $\mathrm{N}$ assimilated by wheat. 
Figures

(a)

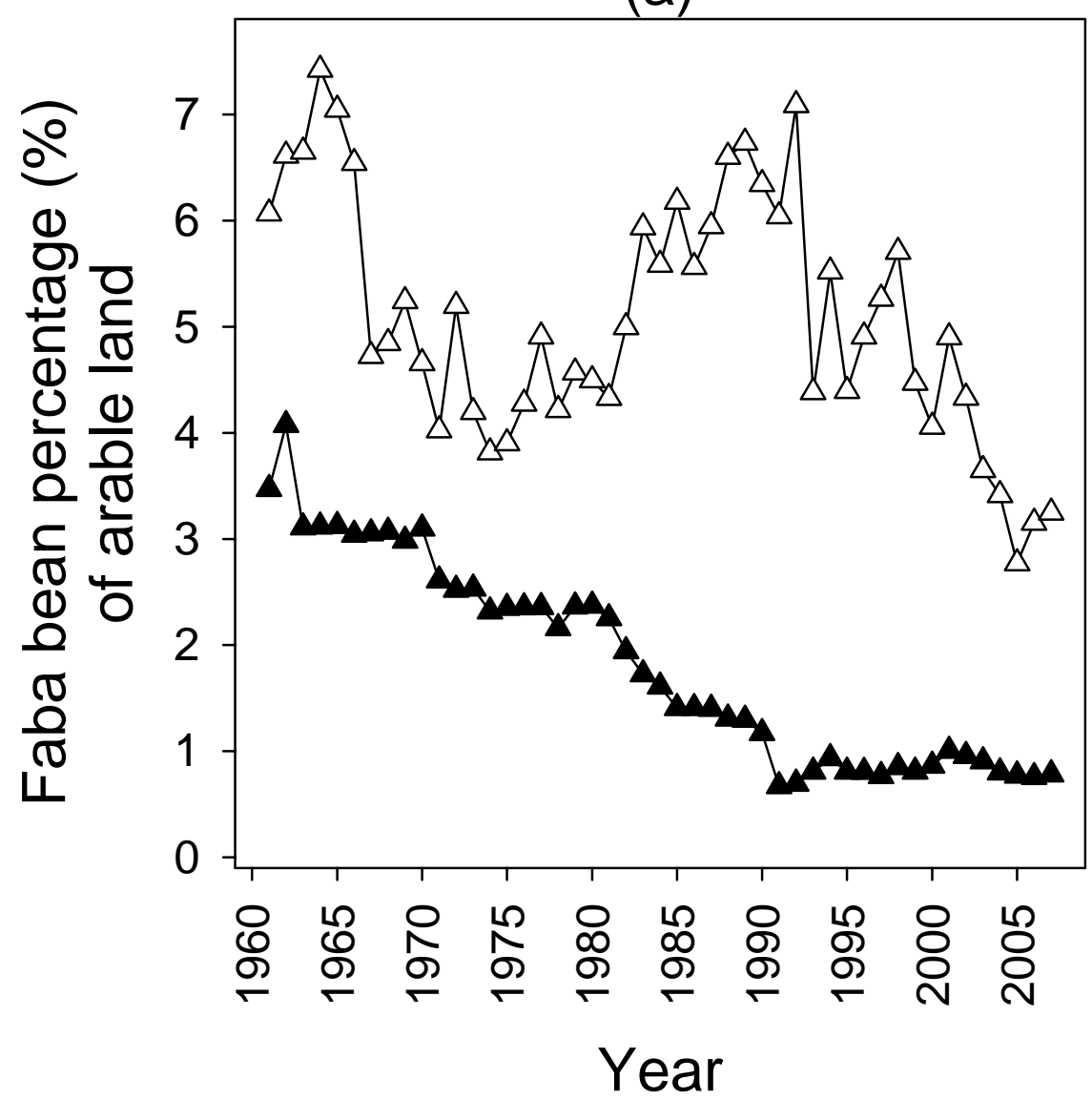

(b)

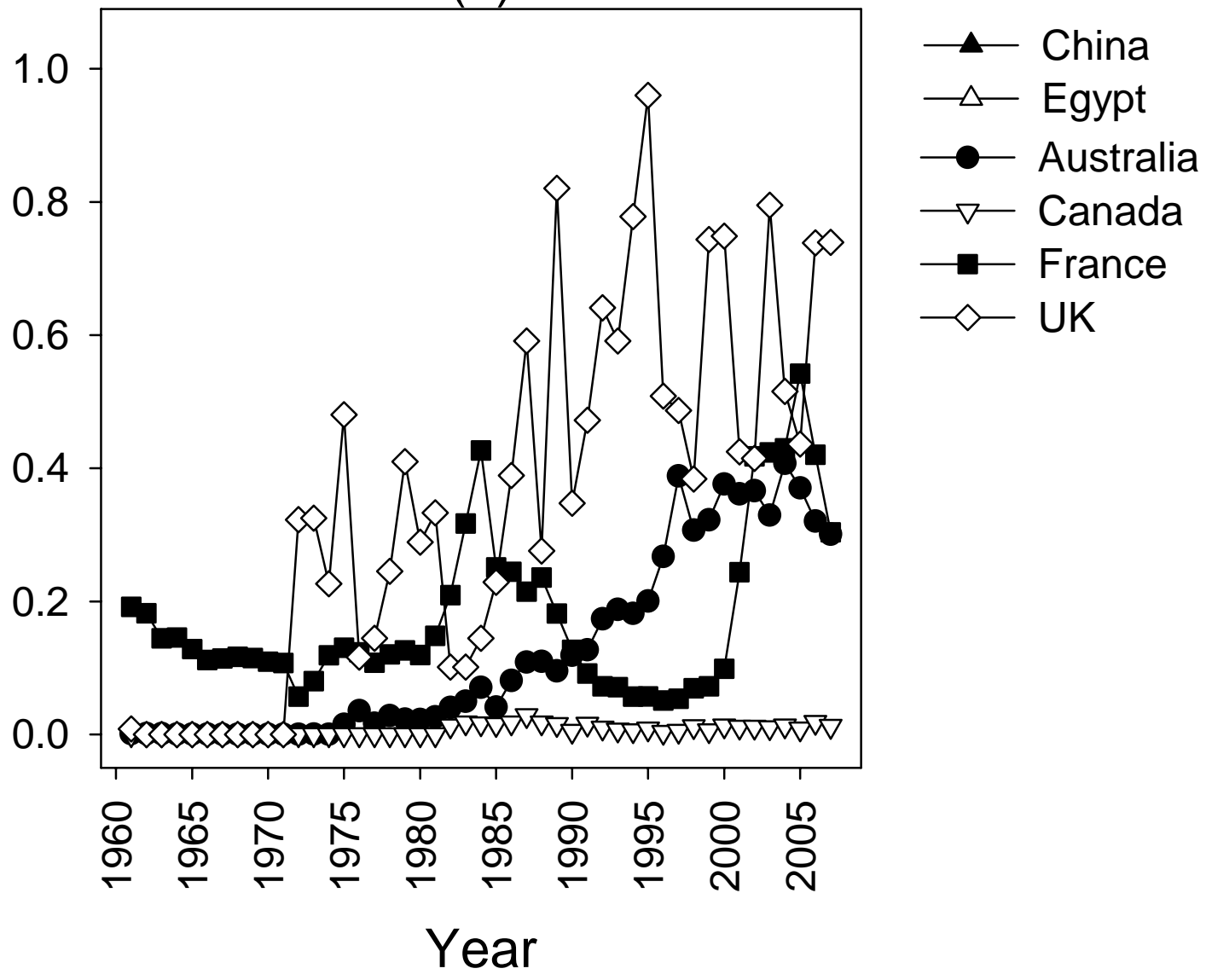

Figure 1. 
(a)

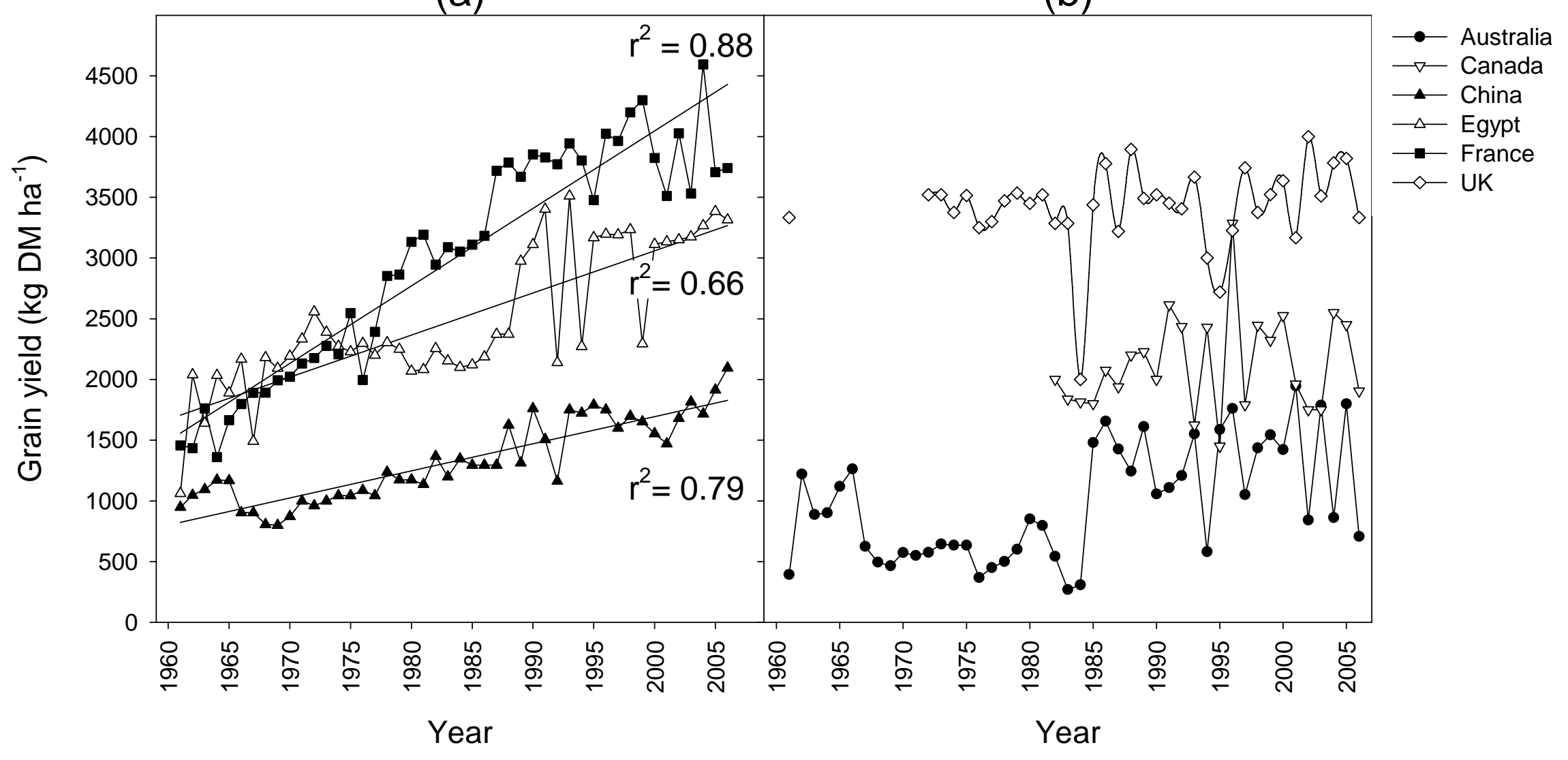

Fig. 2. 
(a)

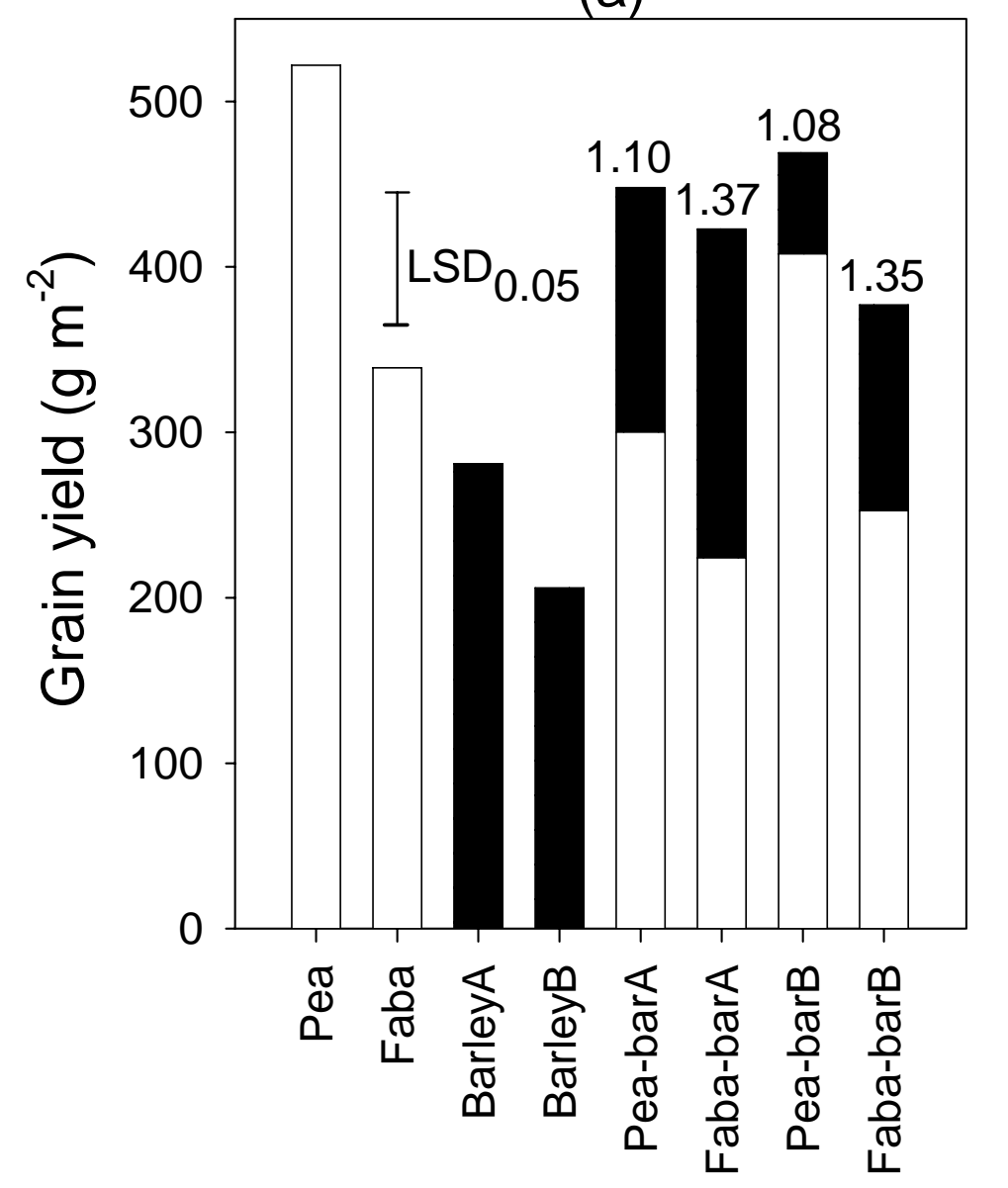

(b)

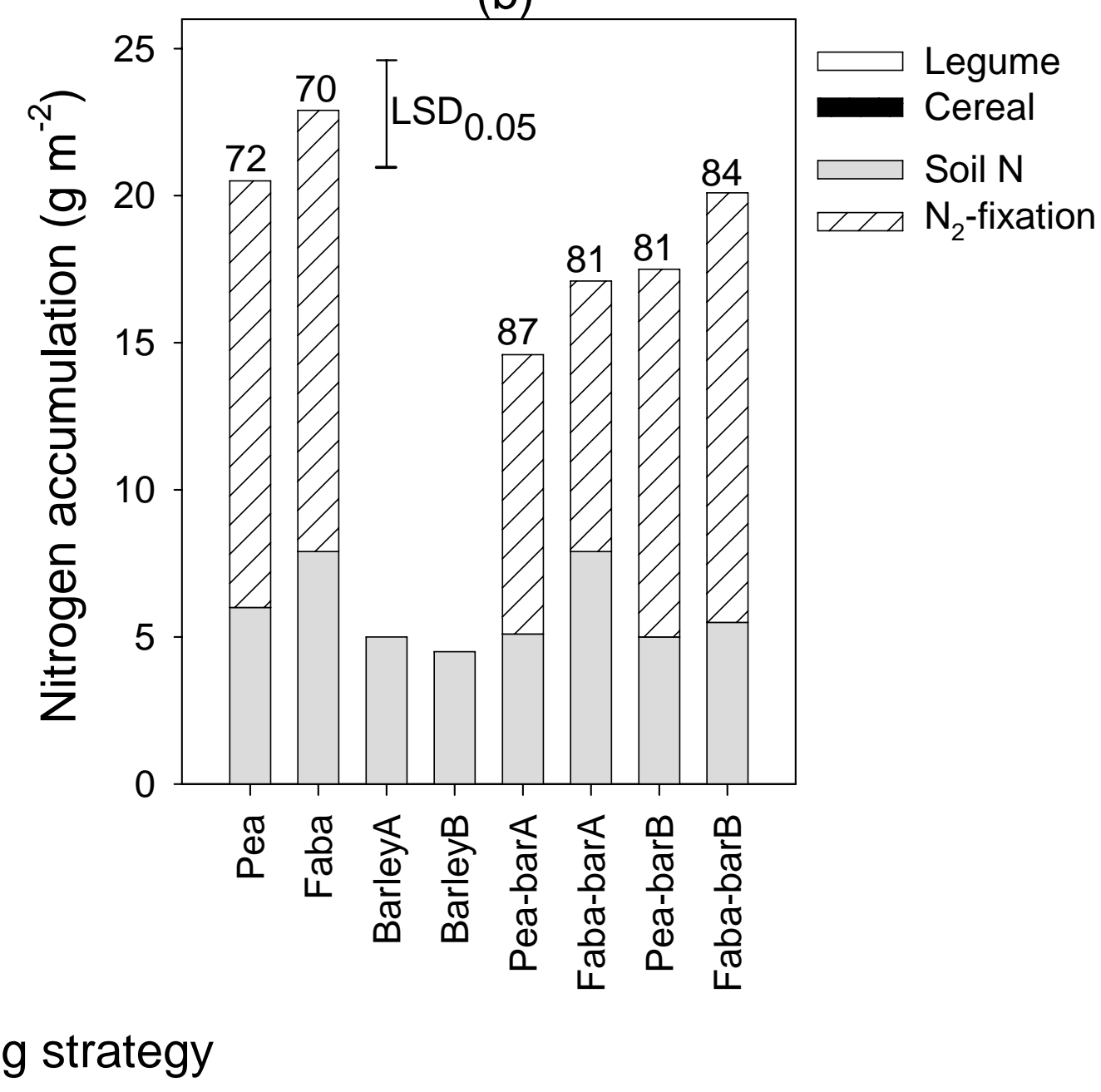

Fig. 3. 


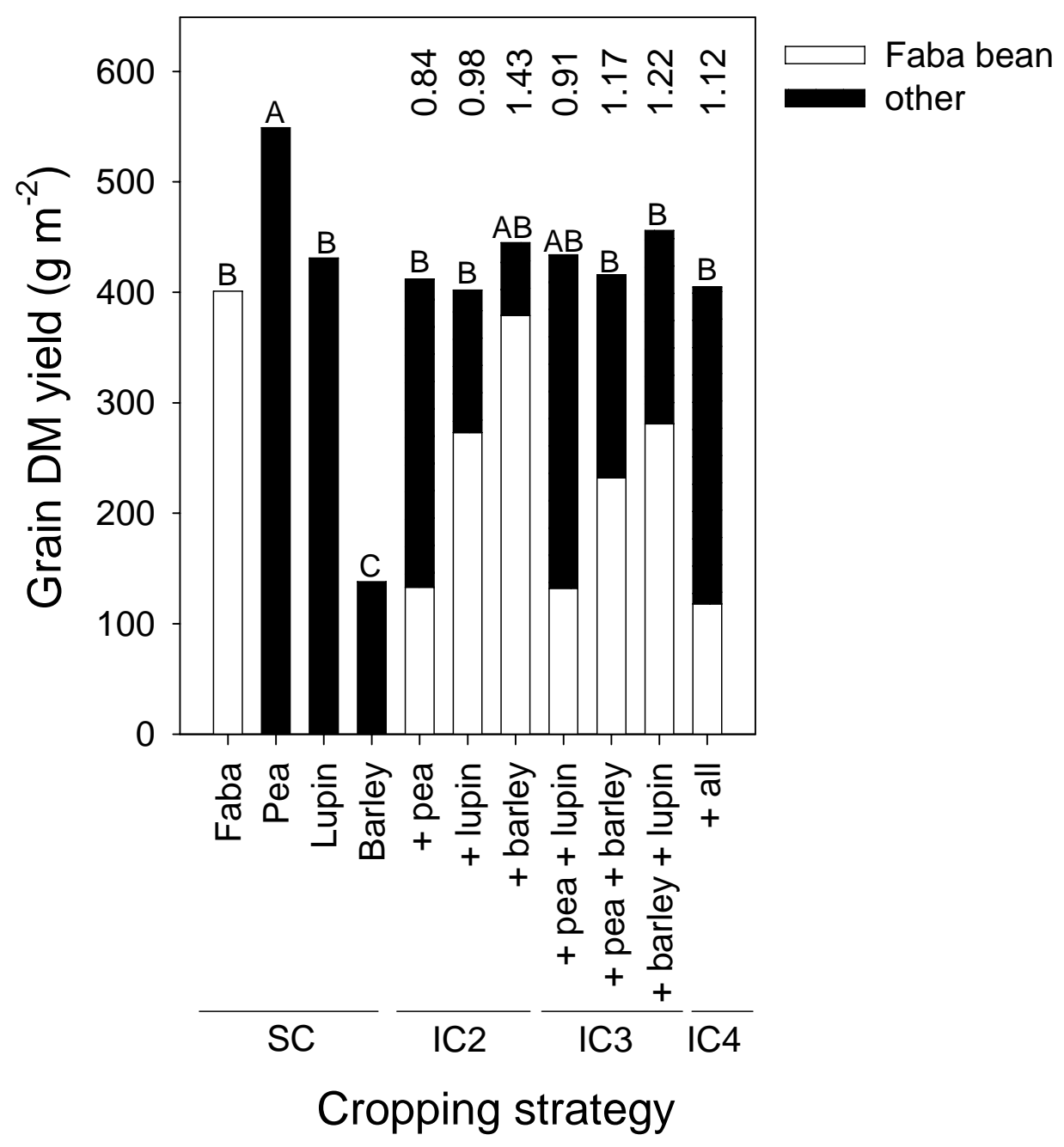

Fig. 4. 
(a) Fertilizer $\mathrm{N}$

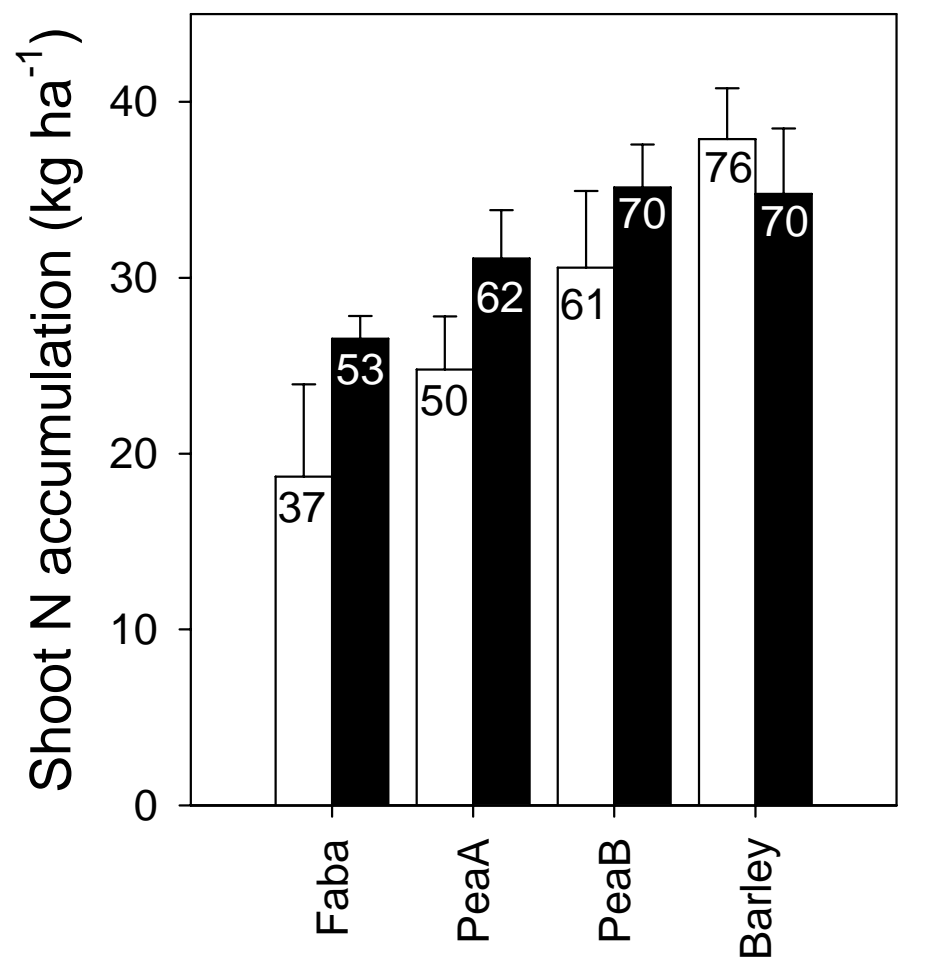

Fig. 5.
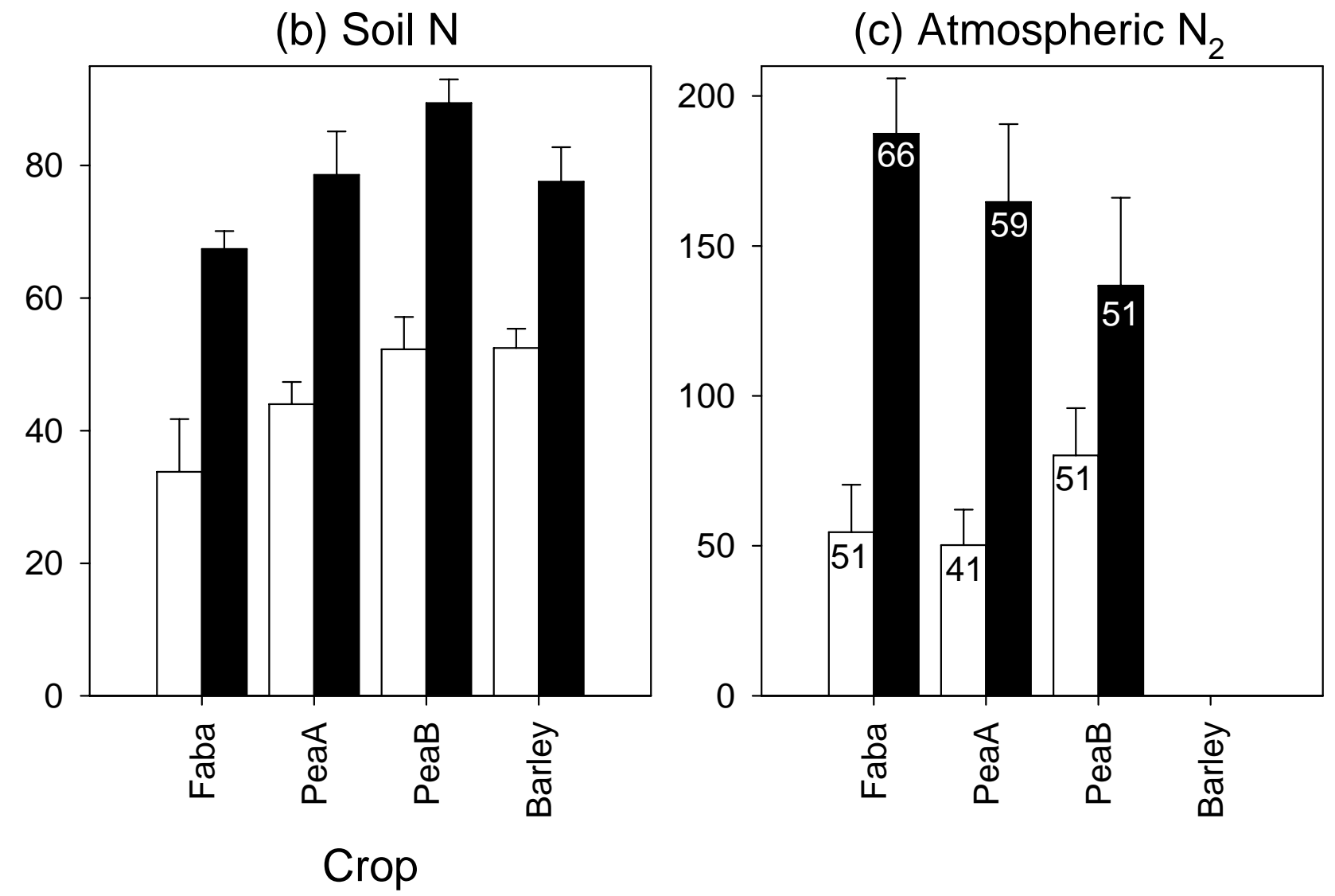


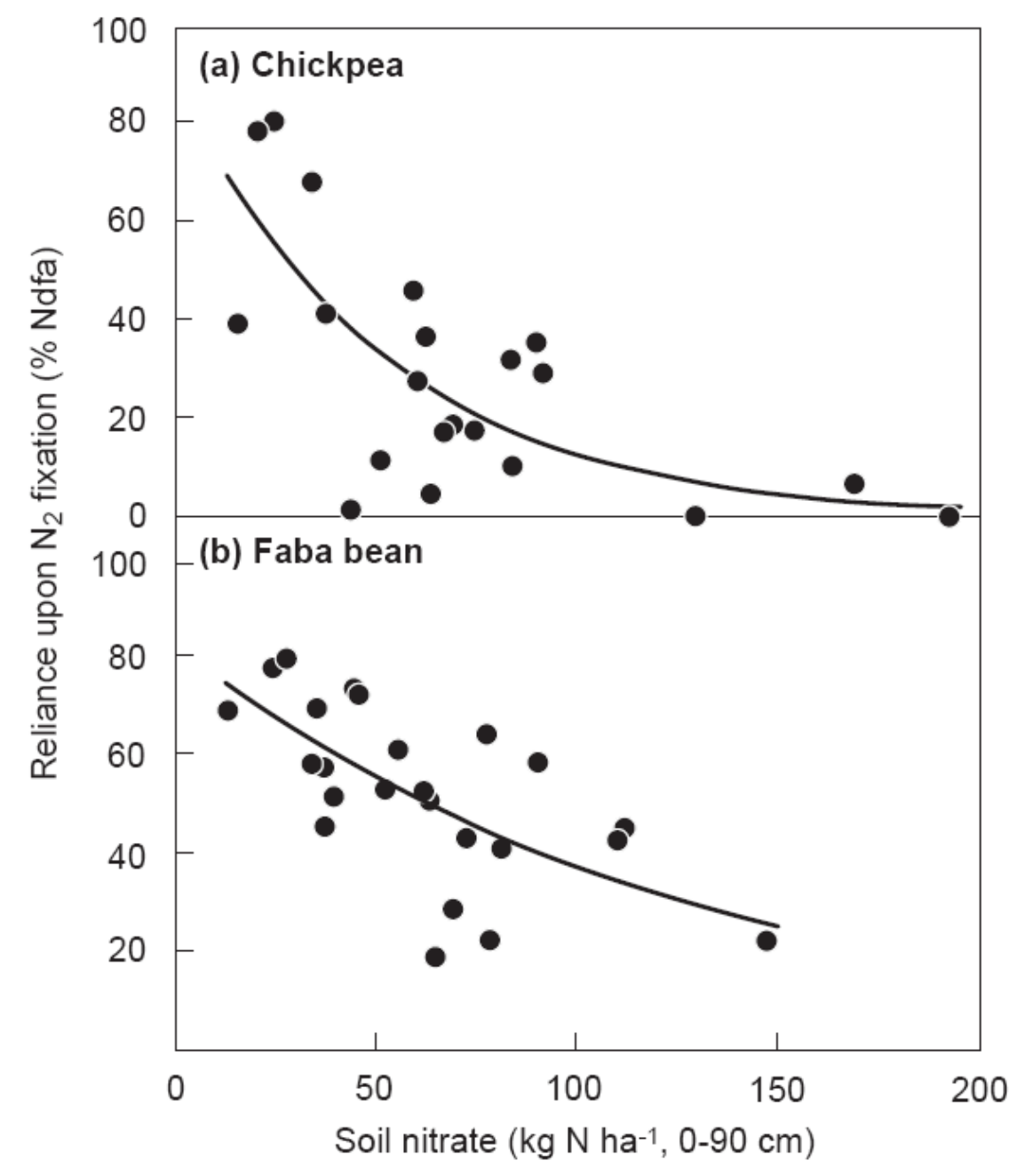

Fig. 6. 


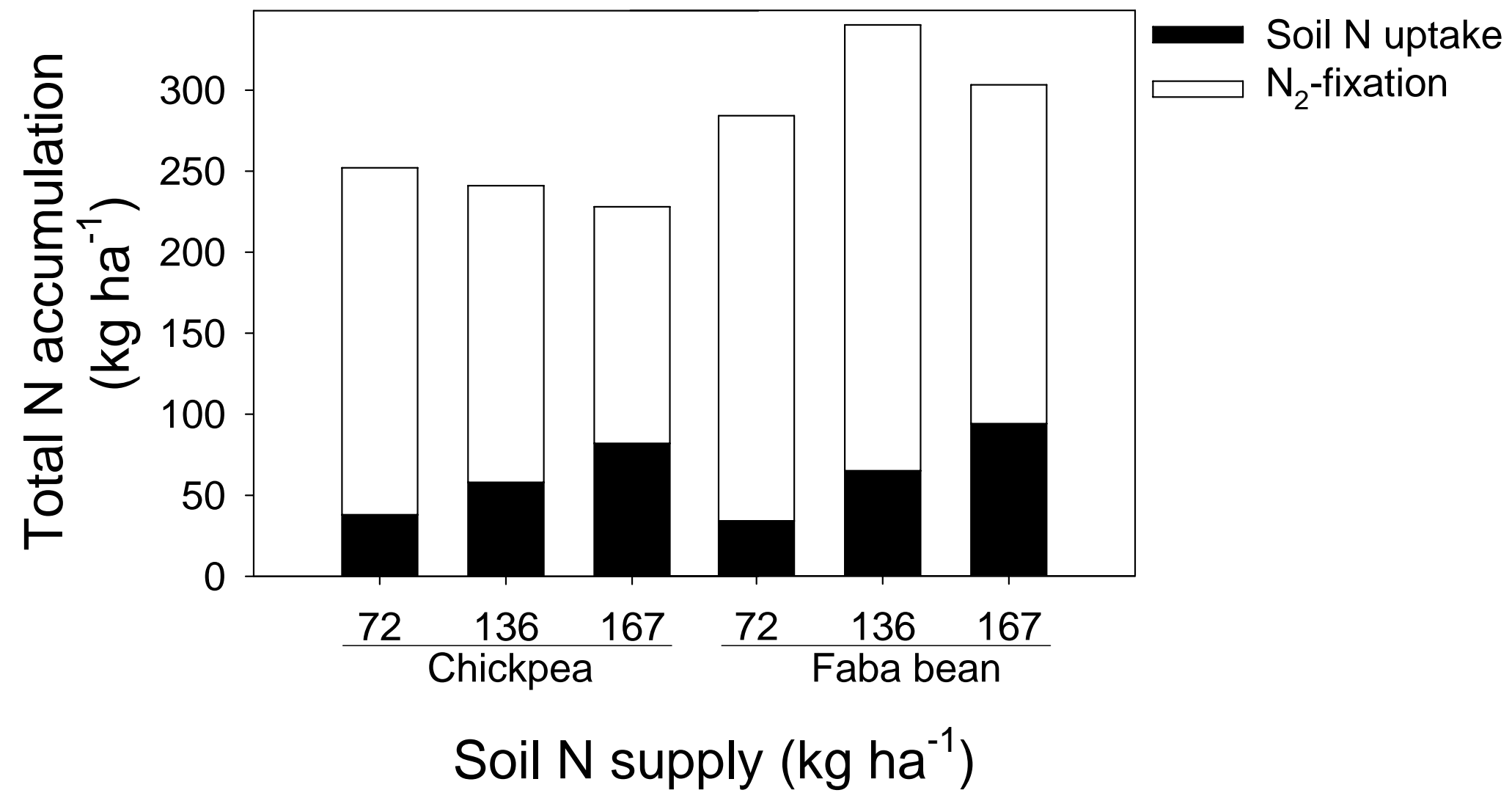

Fig. 7. 
Table 1 Dry matter (DM) production, nutrient concentrations, amounts of nutrients accumulated, and calculated harvest indexes for DM and nutrients for an indeterminate spring-sown faba bean cultivar (cv. Diana) and two pea cultivars*. Crops were grown on a sandy loam soil in Denmark with or without the supply of $50 \mathrm{~kg} \mathrm{~N} \mathrm{ha}^{-1}$. Results are shown as means of $\mathrm{N}$ fertilizer levels and 3 years of experimentation. Results of the pea cultivars are shown as means of the two cultivars (Jensen et al., 1985a)

\begin{tabular}{|c|c|c|c|c|c|c|c|c|c|c|c|c|c|c|}
\hline \multirow[t]{2}{*}{ Plant part } & \multirow[t]{2}{*}{ Crop } & \multirow{2}{*}{$\begin{array}{c}\text { DM yield } \\
\mathrm{gm}^{-2}\end{array}$} & \multicolumn{6}{|c|}{ Nutrient concentrations (\%) } & \multicolumn{6}{|c|}{ Nutrient accumulation $\left(\mathrm{gm}^{-2}\right)$} \\
\hline & & & $\mathrm{N}$ & $\mathrm{P}$ & $\mathrm{K}$ & $\mathrm{Na}$ & $\mathrm{Ca}$ & $\mathrm{Mg}$ & $\mathrm{N}$ & $\mathrm{P}$ & $\mathrm{K}$ & $\mathrm{Na}$ & $\mathrm{Ca}$ & $\mathrm{Mg}$ \\
\hline \multirow[t]{2}{*}{ Seed } & Faba bean & 507 & 4.56 & 0.58 & 1.24 & 0.01 & 0.09 & 0.12 & 23.1 & 2.9 & 6.3 & 0.1 & 0.5 & 0.6 \\
\hline & Pea & 452 & 4.07 & 0.51 & 1.24 & 0.01 & 0.07 & 0.13 & 18.4 & 2.3 & 5.6 & 0.0 & 0.3 & 0.6 \\
\hline \multirow[t]{2}{*}{ Empty pods } & Faba bean & 124 & 1.29 & 0.07 & 3.28 & 0.05 & 0.07 & 0.19 & 1.6 & 0.1 & 4.1 & 0.1 & 0.1 & 0.2 \\
\hline & Pea & 102 & 1.61 & 0.14 & 1.62 & 0.02 & 2.03 & 0.26 & 1.6 & 0.1 & 1.7 & 0.0 & 2.1 & 0.3 \\
\hline \multirow[t]{2}{*}{ Stubble** } & Faba bean & 538 & 1.28 & 0.22 & 1.60 & 0.16 & 1.80 & 0.17 & 6.8 & 0.5 & 8.7 & 0.9 & 9.7 & 1.0 \\
\hline & Pea & 339 & 2.05 & 0.21 & 1.78 & 0.06 & 2.86 & 0.19 & 6.9 & 0.7 & 6.0 & 0.2 & 9.7 & 0.6 \\
\hline \multirow[t]{2}{*}{ Roots } & Faba bean & 75 & 1.01 & 0.07 & 0.92 & 0.25 & 0.57 & 0.08 & 0.8 & 0.1 & 0.7 & 0.2 & 0.4 & 0.1 \\
\hline & Pea & 14 & 2.12 & 0.19 & 0.87 & 0.13 & 2.34 & 0.15 & 0.3 & 0.0 & 0.1 & 0.0 & 0.3 & 0.0 \\
\hline \multirow{2}{*}{$\begin{array}{l}\text { Total in DM } \\
\text { excl. roots }\end{array}$} & Faba bean & 1169 & & & & & & & 31.6 & 3.5 & 19.0 & 1.0 & 10.2 & 1.8 \\
\hline & Pea & 893 & & & & & & & 27.0 & 3.2 & 13.3 & 0.3 & 12.1 & 1.5 \\
\hline \multirow{3}{*}{ Harvest index } & & $\%$ & & & & & & & $\%$ & $\%$ & $\%$ & $\%$ & $\%$ & $\%$ \\
\hline & Faba bean & 43 & & & & & & & 73 & 83 & 33 & 5 & 4 & 34 \\
\hline & Pea & 51 & & & & & & & 68 & 73 & 42 & 17 & 3 & 39 \\
\hline
\end{tabular}

* Cv Bodil is a white-flowed determinate cultivar and Cv Timo is a purple-flowered indeterminate cultivar.

Crops were fertilized with $30 \mathrm{~kg} P$ and $50 \mathrm{~kg} \mathrm{~K} \mathrm{ha}^{-1}$

** Stubble is the sum of stems and leaves.

Plants samples derived from $1 \mathrm{~m}^{-2}$ subplots were analyzed using conventional methods (Kjeldahl for N, spectrometric methods for P and atom absorption for cations.) 
Table 2 Examples of field estimates of the proportions (Ndfa) and amounts of $\mathrm{N}$ fixed the atmosphere and assimilated from soil $\mathrm{N}$ by faba bean.

\begin{tabular}{|c|c|c|c|c|}
\hline $\begin{array}{c}\text { Fertilizer } \mathrm{N} \text { supplied } \\
\text { at sowing } \\
\left(\mathrm{kgN} \mathrm{ha}^{-1}\right)\end{array}$ & $\begin{array}{l}\text { Ndfa } \\
\text { (\%) }\end{array}$ & $\begin{array}{c}\text { Amounts fixed } \\
\left(\mathrm{kg} \text { shoot } \mathrm{N} \mathrm{ha}^{-1}\right)\end{array}$ & $\begin{array}{c}\text { Soil N uptake } \\
\left(\text { kg shoot } \mathrm{N} \mathrm{ha}^{-1}\right)\end{array}$ & Reference \\
\hline 120 & 34 & 134 & 260 & Fan et al. (2006) \\
\hline 100 & 69 & 197 & 89 & Fried and Broeshart (1975) \\
\hline 50 & 66 & 188 & 96 & Jensen (1986c) \\
\hline 30 & 58 & 160 & 115 & Witty (1983) \\
\hline 30 & 88 & 94 & 8 & Lopez-Bellido et al. (2006) \\
\hline $18-72$ & 66 & 83 & 42 & Schmidt et al. (1987) \\
\hline 20 & 69 & 204 & 92 & Sparrow et al. (1995) \\
\hline 10 & 84 & 190 & 36 & Rennie and Dubetz (1986) \\
\hline 2 & 40 & 73 & 109 & Haynes et al. (1993) \\
\hline 0 & 44 & 217 & 276 & Patriquin (1986) \\
\hline 0 & 58 & 220 & 159 & Fan et al. (2006) \\
\hline 0 & 70 & 255 & 109 & Stülpnagel (1982) \\
\hline 0 & 72 & 155 & 60 & Hauggaard-Nielsen et al. (2008) \\
\hline 0 & 74 & 177 & 62 & Rochester et al. (1998) \\
\hline 0 & 78 & 128 & 36 & Peoples et al. (2001) \\
\hline 0 & 79 & 136 & 36 & Richards and Soper (1982) \\
\hline 0 & 86 & 114 & 29 & Rochester et al. (2001) \\
\hline 0 & 99 & 335 & 3 & Hauggaard-Nielsen et al. (2009) \\
\hline
\end{tabular}


Table 3. Comparison of estimates of the proportions (Ndfa) and amounts of shoot $\mathrm{N}$ fixed by faba bean with other important cool-season legume crops in different geographical regions of the world .

\begin{tabular}{|c|c|c|c|c|}
\hline \multirow[t]{2}{*}{$\begin{array}{l}\text { Legume species } \\
\text { Region }\end{array}$} & \multicolumn{2}{|c|}{$\begin{array}{c}\text { Ndfa } \\
(\%)\end{array}$} & \multicolumn{2}{|c|}{$\begin{array}{c}\text { Amount fixed } \\
\left(\mathrm{kg}^{2} \text { shoot } \mathrm{N} \mathrm{ha}{ }^{-1}\right)\end{array}$} \\
\hline & range & mean & range & mean \\
\hline \multicolumn{5}{|c|}{ Pea (Pisum sativum): total area grown $=10.4$ Mha } \\
\hline West Asia & $70-74$ & 72 & $33-62$ & 47 \\
\hline Europe & 26-99 & 60 & $28-215$ & 130 \\
\hline North America & $0-87$ & 56 & 11-196 & 83 \\
\hline Oceania & 31-95 & 68 & $26-183$ & 83 \\
\hline Overall mean & & 62 & & 86 \\
\hline \multicolumn{5}{|c|}{ Chickpea (Cicer arietinum): total area grown $=6.6 \mathrm{Mha}$} \\
\hline South Asia & $25-97$ & 60 & $18-80$ & 36 \\
\hline West Asia & $8-91$ & 60 & 3-115 & 51 \\
\hline Europe & $44-77$ & 56 & $23-74$ & 43 \\
\hline North America & $0-92$ & 50 & $24-84$ & 54 \\
\hline Oceania & $37-86$ & 60 & $43-124$ & 70 \\
\hline Overall mean & & 57 & & 51 \\
\hline \multicolumn{5}{|c|}{ Lentil (Lens culinaris): total area grown $=4.4 \mathrm{Mha}$} \\
\hline South Asia & $9-97$ & 65 & $4-90$ & 42 \\
\hline West Asia & $58-68$ & 64 & $110-152$ & 122 \\
\hline North America & 7-89 & 60 & $4-145$ & 50 \\
\hline Overall mean & & 63 & & 71 \\
\hline \multicolumn{5}{|c|}{ Faba bean (Vicia faba): total area grown $=2.6 \mathrm{Mha}$} \\
\hline East Asia & $52-73$ & 61 & $158-413$ & 239 \\
\hline West Asia & $63-76$ & 69 & 78-133 & 100 \\
\hline Europe & $60-92$ & 74 & $73-211$ & 153 \\
\hline North Americab & $60-92$ & 88 & $13-252$ & 135 \\
\hline Oceania & $69-89$ & 82 & $82-216$ & 143 \\
\hline Overall mean & & 75 & & 154 \\
\hline \multicolumn{5}{|c|}{$\begin{array}{l}\text { a Adapted from data and publications cited by Fan et al. (2006); Walley et al. (2007); Herridge } \\
\text { et al. (2007); Peoples et al. (2009a); Li et al. (2009). Data from N fertilized treatments have } \\
\text { not been included. Total global area grown by each crop derived from FAOSTA (2008). } \\
\text { b Note: most of the faba bean data from North America come from irrigated crops, elsewhere } \\
\text { in the world the data come from a mixture of rain-fed and irrigated crops. }\end{array}$} \\
\hline
\end{tabular}


Table 4. Comparison of the proportion of plant $\mathrm{N}$ derived from $\mathrm{N}_{2}$ fixation (Ndfa) and estimates of the amounts of $\mathrm{N}_{2}$ fixed by commercial faba bean crops with other pulses in the farming systems of eastern Australia ${ }^{\mathrm{a}}$.

\begin{tabular}{lccc}
\hline Legume & $\begin{array}{c}\text { Number } \\
\text { of crops }\end{array}$ & $\begin{array}{c}\text { Mean Ndfa } \\
(\%)\end{array}$ & $\begin{array}{c}\text { Shoot N fixed } \\
\left(\mathrm{kg} \mathrm{N} \mathrm{ha}^{-1}\right)\end{array}$ \\
\hline Faba bean & 56 & 68 & 95 \\
Pea, Chickpea, Lentil & 33 & 56 & 71
\end{tabular}

${ }^{a}$ Values derived from information presented by Rochester et al. (1998); Schwenke et al. (1998); Peoples et al. (2001); Peoples et al. (2009a). 
Table 5 Calculations of the impact of faba bean or barley on the $\mathrm{N}$ dynamics of a following wheat crop based on comparisons of $\mathrm{N}$ accumulated by wheat, or using ${ }^{15} \mathrm{~N}$-based estimates of wheat's direct uptake of faba bean- $\mathrm{N}^{\mathrm{a}}$

\begin{tabular}{lcc}
\hline Parameter & \multicolumn{2}{c}{ Cropping sequence } \\
\cline { 2 - 3 } & $\begin{array}{c}\text { Faba bean } \\
\text { Wheat }\end{array}$ & $\begin{array}{c}\text { Barley - } \\
\text { Wheat }\end{array}$ \\
\hline Residue N from faba bean or barley $\left(\mathrm{kg} \mathrm{N} \mathrm{ha}^{-1}\right)$ & $96^{\mathrm{b}}$ & $73^{\mathrm{b}}$ \\
Wheat N at maturity $\left(\mathrm{kg} \mathrm{N} \mathrm{ha}^{-1}\right)$ & 97 & 59 \\
Wheat N benefit from legume $\left(\mathrm{kg} \mathrm{N} \mathrm{ha}^{-1}\right)$ & $38^{\mathrm{c}}$ & $40^{\mathrm{d}}$ \\
Apparent recovery of faba bean N (\%) & & \\
& & \\
${ }^{15} \mathrm{~N}$-based estimated recovery of faba bean N (\%) & $3^{\mathrm{e}}$ \\
- from shoot residues & $8^{\mathrm{e}}$ \\
- from nodulated roots and rhizodeposition & $11^{\mathrm{e}}$ \\
Total & &
\end{tabular}

${ }^{\mathrm{a}}$ Modified from data presented by Peoples et al. (2009a).

${ }^{\mathrm{b}}$ Includes shoot $\mathrm{N}$ remaining after grain harvest and an estimate of below-ground $\mathrm{N}$.

${ }^{\mathrm{c}}$ Calculated as: (wheat $\mathrm{N}$ after faba bean) - (wheat $\mathrm{N}$ after barley)

${ }^{\mathrm{d}}$ Calculated as: $100 \mathrm{x}$ (wheat $\mathrm{N}$ benefit) $/($ faba bean residue $\mathrm{N})=100 \times(38) /(96)=40 \%$

${ }^{\mathrm{e}}$ Calculated from the measured recovery of the legume residue ${ }^{15} \mathrm{~N}$ present in the wheat crop. 